\title{
Neuroepigenetic mechanisms in disease
}

\author{
Michael A. Christopher ${ }^{1,2 \dagger}$, Stephanie M. Kyle ${ }^{1 \dagger}$ and David J. Katz ${ }^{1 *}$ (D)
}

\begin{abstract}
Epigenetics allows for the inheritance of information in cellular lineages during differentiation, independent of changes to the underlying genetic sequence. This raises the question of whether epigenetic mechanisms also function in post-mitotic neurons. During the long life of the neuron, fluctuations in gene expression allow the cell to pass through stages of differentiation, modulate synaptic activity in response to environmental cues, and fortify the cell through age-related neuroprotective pathways. Emerging evidence suggests that epigenetic mechanisms such as DNA methylation and histone modification permit these dynamic changes in gene expression throughout the life of a neuron. Accordingly, recent studies have revealed the vital importance of epigenetic players in the central nervous system and during neurodegeneration. Here, we provide a review of several of these recent findings, highlighting novel functions for epigenetics in the fields of Rett syndrome, Fragile X syndrome, and Alzheimer's disease research. Together, these discoveries underscore the vital importance of epigenetics in human neurological disorders.
\end{abstract}

Keywords: Neuroepigenetics, DNA methylation, Histone modification, Rett syndrome, Fragile X syndrome, Alzheimer's disease, MECP2, FMR1, LSD1/KDM1A

\section{Introduction to neuroepigenetics}

Advances in molecular biology and genomics have allowed researchers to uncover roles for epigenetic regulation in a diversity of biological processes previously unexplained by classical genetics. These epigenetic mechanisms manifest as a variety of chromatin modifications and states, altering gene function in a transient or persistent manner and acting as a vector for the passage of information. For example, considerable attention has been paid to the contributions of epigenetic aberrations during oncogenesis. In fact, epigenetic changes have been designated as one of the hallmarks of cancer [1-3]. Oncogenic phenotypes can arise when an insult or a mutation in an epigenetic pathway creates heritable epigenetic information that is passaged through mitosis. However, mature neurons no longer undergo mitosis and thus do not have an obligation to pass information onto daughter cells. This makes the developed nervous system an interesting system to study epigenetic regulation. What epigenetic regulation is required in post-mitotic

\footnotetext{
*Correspondence: djkatz@emory.edu

${ }^{\dagger}$ Michael A. Christopher and Stephanie M. Kyle contributed equally to this work

${ }^{1}$ Department of Cell Biology, Emory University School of Medicine, 615 Michael Street, Atlanta, GA 30322, USA

Full list of author information is available at the end of the article
}

neurons, and how is it established and maintained? Are there consequences for misregulation of these processes that manifest in human disease? If so, it will be important to determine the contribution of epigenetic mechanisms to complex diseases such as autism spectrum disorders (ASD) and neurodegenerative disorders, where identification of a purely genetic etiology has been elusive. In the first part of this review, we introduce our current understanding of epigenetic modifications, with an emphasis on what is known about them in post-mitotic neurons. In the second part of this review, we highlight how disruption of these processes may contribute to three specific examples of neurological disease. Importantly, this review is not intended as a comprehensive summary of all that is known about neuroepigenetics (for more information on neuroepigenetics, please see [4-6]. Rather, we hope that it will serve as an entry point for researchers from multiple fields to begin to consider how post-mitotic neurons may have unique epigenetic requirements, and how epigenetic mechanisms may contribute to neurological disease.

\section{Epigenetic modifications and their regulators DNA methylation}

One level of chromatin modification is the methylation of DNA at cytosine residues and, as recently discovered, 
on adenosine residues. Given the size and complexity of the vertebrate genome, methylated DNA adds a layer of regulation that further refines the cellular transcriptional profile. Cytosine methylation in mammals occurs primarily in a CpG dinucleotide context in most cell types. It has been most extensively studied in the context of CpG islands: genomic regions containing a higher rate of $\mathrm{CpG}$ dinucleotides than the rest of the genome $[7,8]$. These regions are thought to be evolutionarily conserved regulatory elements, as CpGs are underrepresented in the genome due to spontaneous deamination of methylcytosine into thymine, resulting in a $T / G$ mismatch. If this mismatch is not detected as a mutation by the DNA repair pathway, it results in a C/G to T/A transition mutation in the resulting daughter strand [9]. Thus, preservation of $\mathrm{CpGs}$ at $\mathrm{CpG}$ islands is thought to occur via positive selection at evolutionarily conserved promoters. Cytosine methylation at $\mathrm{CpG}$ dinucleotides in promoters is correlated with repressed transcription, while cytosine methylation in gene bodies, as well as methylation of adenosines, appears to be correlated with an active transcriptional state in many cells [10-14]. A notable exception to this trend occurs within neurons, where cytosine methylation within gene bodies is anticorrelated with transcription $[15,16]$. Cytosine methylation occurs by the addition of a methyl group to the fifth position of the cytosine base $(5 \mathrm{mC})$ and is donated by $S$-adenosylmethionine. This reaction is carried out by DNA methyltransferase (DNMT) enzymes. DNMT3a and DNMT3b can methylate cytosines de novo [17]. DNMT1 recognizes palindromic hemimethylated CpG dinucleotides and adds a methyl group to the unmethylated cytosine on the opposite strand [18]. Through the action of DNMT1, the maintenance methyltransferase, DNA methylation can be inherited through DNA replication and cell division, though it remains possible that DNMT1 has de novo methyltransferase activity in certain contexts.

However, this paradigm is challenged in the context of a post-mitotic neuron. Within the context of mature neurons, methylated $\mathrm{CpG}$ dinucleotides were once thought to be very stable; however, DNA methylation is dynamically regulated in the adult nervous system $[19,20]$. This mechanism is crucial in synaptic plasticity and memory formation [21, 22]. Specifically, work from the Sweatt Lab found that non-specific inhibition of DNMT activity altered DNA methylation in the adult brain and changed the methylation landscape surrounding plasticity promoting genes such as brain-derived neurotrophic factor (BDNF) [23]. Remarkably, the group determined that DNA hypermethylation occurs in a locus-specific manner following a single associative learning experience. Further, pharmacological inhibition of DNA methylation abolished remote memory in rats [24]. In addition,
Fan and colleagues have provided further evidence that mature neurons require active maintenance of DNA methylation. The researchers showed that when both Dnmt1 and Dnmt3a are deleted in post-mitotic excitatory neurons, mice display learning and memory deficits without neuronal loss. This phenotype only occurred when both methyltransferases were deleted, suggesting that the enzymes redundantly regulate neuronal processes in adult excitatory neurons. Hippocampi from double Dnmt1/3a mutant animals displayed abnormal long-term potentiation following stimulation, suggesting the learning deficits are due to neuronal plasticity errors. Genes involved in immune response, cell communication, and mRNA transcriptional regulation were also aberrantly expressed in double mutant mice brains due to hypomethylation of their promoter regions. This study demonstrates that the DNA methyltransferases play redundant roles in post-mitotic neurons by regulating gene expression associated with neuronal homeostasis, which affects higher-order functions like learning and memory. Fan and colleague's findings suggest that DNA demethylation occurs at promotor regions in the absence of Dnmt1 and Dnmt3a [25]. This was surprising, as it suggests a role for Dnmt1, a methyltransferase that typically transmits DNA methylation to daughter cells, in the maintenance of DNA methylation in non-dividing adult neurons [25].

Recently, some DNA demethylation by-products have been described as biologically functional, suggesting that DNA methylation and demethylation are dynamic processes. $5 \mathrm{mC}$ can be oxidized to form 5 -hydroxymethylcytosine $(5 \mathrm{hmC}), 5$-formylcytosine $(5 \mathrm{fC})$, and 5-carboxylcytosine $(5 \mathrm{caC})$ in sequential reactions carried out by the ten-eleven translocase (TET) family of enzymes $[26,27]$. This series of oxidation reactions is thought to be a mechanism of active demethylation, rather than one of passive demethylation, which occurs through DNA replication [28]. The $5 \mathrm{hmC}$ mark is most highly enriched in the brain when compared to any other tissue [29-31], and TET1, which catalyzes the conversion of $5 \mathrm{mC}$ to $5 \mathrm{hmC}$, is activated by neuronal activity [19]. Current evidence suggests that within the brain, $5 \mathrm{hmC}$ is acquired in a developmentally dependent manner, occurs exclusively in the CpG context, and is enriched in the gene bodies of highly expressed genes $[16,31,32]$. This suggests a role for $5 \mathrm{hmC}$ in active transcription within neurons [32]. Indeed, Sweatt and colleagues have shown that TET1 expression positively regulates subsets of genes associated with learning and memory [19]. Further, Rudenko et al. [33] found gross downregulation and hypermethylation of activity-related genes, including Npas4, c-Fos, and Arc in a TET1 null mouse model. Unsurprisingly, TET1 null animals display impaired synaptic plasticity and 
memory extinction. TET3 similarly regulates synaptic transmission in an activity-dependent manner. Knockdown or TET3 or inhibition of base excision repair, the process by which an oxidized cytosine is replaced with an unmethylated cytosine, elevates glutamatergic signaling in hippocampal neurons, whereas overexpression of TET3 decreases it [34].

$5 \mathrm{fC}$ and $5 \mathrm{caC}$ are found at extremely low levels in the embryonic stem cell genome (at major satellite repeats), but accumulate in regulatory regions when thymineDNA glycosylase (TDG) is depleted [35]. TDG removes the $5 \mathrm{caC}$ base to allow for base excision repair enzymes to replace the abasic site with an unmethylated cytosine [36]. This suggests there is dynamic demethylation of cytosines occurring in embryonic stem cells at regulatory regions. This could mean that $5 \mathrm{fC}$ and $5 \mathrm{caC}$ are simply reaction intermediates that can be captured, but are normally found at low levels at specific loci. Currently, their epigenetic role is unclear; however, a recent study showed that $5 \mathrm{fC}$ and $5 \mathrm{caC}$ reduce RNA polymerase II elongation rate and therefore may influence splicing [37].

Methylated cytosine in the context of $\mathrm{CpG}$ dinucleotides was historically thought to be the sole form of DNA methylation. However, it is now recognized that cytosine methylation does not occur exclusively in the CpG context $[16,38,39]$. Mapping of DNA methylation with single base pair resolution has found that it also occurs in a non-CpG context (termed $5 \mathrm{mCH}$, where $\mathrm{H}$ is an $\mathrm{A}$, $\mathrm{T}$, or C) [40]. The highest levels of $5 \mathrm{mCH}$ have been observed in neurons and embryonic stem cells $[14,16]$. This enrichment of $5 \mathrm{mCH}$ in these cell types suggests it may have cell type-specific roles. $5 \mathrm{mCH}$ is lost during embryonic stem cell differentiation and then reacquired by neurons during neuronal maturation $[16,39,40] .5 \mathrm{mCH}$ methylation requires DNMT3a for active maintenance in post-mitotic neurons [39], and $5 \mathrm{mCH}$ may play a critical role in the specification of neuronal subtypes. Recent work from Ecker, Nathans, and colleagues describes how the DNA methylome predicts current and previous cell type gene expression [41]. Using the INTACT method for nuclei purification [42], they isolated three different neuron subtypes (excitatory pyramidal neurons, parvalbumin interneurons, and vasoactive intestinal peptide interneurons) and performed RNA-seq along with MethylC-seq. This allowed for generation of matching transcriptome and DNA methylome datasets from the different neuronal subtypes. They found that gene body $5 \mathrm{mCH}$ correlates more strongly with repressed transcription across all three neuronal subtypes, more so than any other DNA methylation pattern $(5 \mathrm{mCH}$ and $5 \mathrm{mCG}$ in promoters and $5 \mathrm{mCG}$ in gene bodies). This finding suggests that gene body $5 \mathrm{mCH}$ is tightly linked to transcriptional control beyond other contexts of DNA methylation in neurons and may be part of the epigenetic program that defines neuron subtype specification [41]. As $5 \mathrm{CH}$ methylation is acquired during neuronal differentiation, it raises the question: do aberrations in writing or reading this modification underlie neurological disease?

\section{Histone modifications}

Histones are a highly conserved set of proteins that assemble in an octamer composed of pairs of $\mathrm{H} 2 \mathrm{~A}, \mathrm{H} 2 \mathrm{~B}$, $\mathrm{H} 3$, and H4. Following replication, DNA is first complexed with $\mathrm{H} 3$ and $\mathrm{H} 4$, and $\mathrm{H} 2 \mathrm{~A}$ and $\mathrm{H} 2 \mathrm{~B}$ are deposited to form nucleosomes [43, 44]. Histone proteins can be posttranslationally modified at their $\mathrm{N}$-terminal tails, which are less structured than the core of the octamer. These histone modifications add another layer of epigenetic information and transcriptional control by affecting the three-dimensional structure of the chromatin $[45,46]$. Importantly, these modifications are reversible, allowing for dynamic regulation of nucleosome organization and chromatin structure. For example, a subset of histone modifications is associated with tight nucleosome packaging which prevents transcription of genes at the locus, while other histone modifications relax the chromatin structure and allow the transcriptional machinery to access genes. The posttranslational modifications of histones are controlled by "writers" and "erasers." Writers, like histone methyltransferases or acetyltransferases [47-49], establish histone modifications, whereas erasers, like histone demethylases and deacetylases, remove histone modifications $[50,51]$. These chromatin modifications are then functionally recognized by "readers," enzymes like chromatin remodelers that recognize certain modifications to manipulate chromatin [52-54]. This language of histone modifications and their influence on chromatin has been termed the "histone code" [55]. For a comprehensive review on histone posttranslational modifications, please see $[56,57]$.

A wide range of modifications have been described. Phosphorylation of histone tails appears to result from signal transduction pathways. For example, phosphorylation of serine 10 on histone 3 (H3S10p) is acquired in genes after response to stimulation, such as growth factors [58], and marks mitotic cells. Acetylation of lysine residues is thought to promote euchromatin formation by reducing the positive charge of lysine side chains, thereby disrupting the electrochemical attraction of the positively charged histones to the negatively charged backbone of the DNA. This can be functionally seen by the disruption of the $30 \mathrm{~nm}$ fiber (a proposed higher-order structure of chromatin) by H4K16 acetylation [46].

Methylation of specific histone-lysine residues also influences chromatin shape, but in a more complex manner. One of the most highly studied methylation marks 
is H3K4 methylation, which is associated with active transcription. H3K4 can be mono-, di-, or trimethylated by the mixed lineage leukemia (MLL) and SET family enzymes [59-62]. H3K4me3 is found primarily in the promoters of active and poised genes, while H3K4me2 is found in the gene bodies and enhancers associated with active genes. H3K4me1 is found in enhancers, as well as in promoters, and at the $3^{\prime}$ end of active genes [63]. Mono- and dimethylation of H3K4 is removed by the amine oxidase containing lysine-specific demethylase 1 (LSD1/KDM1A) and lysine-specific demethylase 2 (LSD2/KDM1B). However, amine oxidase demethylases are incapable of removing trimethylation. This is accomplished by a set of Jumonji domain (Jmj) containing demethylases, JARID1a/KDM5A and JARID1b/KDM5B $[64,65]$. Another well-studied modification is H3K9me, which is associated with gene repression. Methylation of H3K9 is established by several methyltransferases, including SUV39H1, G9a (EHMT1), and SETDB1 (ESET) $[66,67]$. H3K9 is primarily found di- and trimethylated and often coincident with DNA methylation in mammalian genomes. It has been proposed that $\mathrm{H} 3 \mathrm{~K} 9$ methylation and DNA methylation can be inherited together through cell division $[68,69]$. H3K9 methylation is erased by the Jmj domain-containing JHDM2A/KDM3A [70]. Modification of $\mathrm{H} 3 \mathrm{~K} 27$ is primarily found in the form of trimethylation and is established by EZH2 of the polycomb repressive complex 2 (PRC2) [71]. It is erased by the Jmj-containing enzymes UTX/KDM6A and JMJD3/ KDM6B [72, 73]. DNA methylation and H3K27me3 are mutually exclusive in the genome, but the significance of this relationship is unclear [74]. These examples highlight the complex interplay between histone methylation and other epigenetic regulators.

Studies have demonstrated that histone modifications and chromatin remodeling are required to facilitate dynamic, complex tasks such as synaptic plasticity, learning, and long-term memory formation. Genetic or pharmacological manipulation of histone acetylation and deacetylation results in a myriad of learning and memory impairments. Specifically, deletion of HDAC2 embryonically results in enhanced long-term potentiation (LTP) and fear conditioning, while overexpression impairs fear condition and spatial learning [75]. Deletion of HDAC2 postnatally in glutamatergic neurons similarly recapitulated these findings [76]. However, mice with a deletion of HDAC1 have no overt phenotypes suggesting that HDAC2 deacetylates in a memory and learning-specific capacity [75]. Alternatively, deletion of HDAC4 in brain results in impaired hippocampal-dependent learning and memory and long-term memory formation [77]. Further, haploinsufficiency of HDAC4 causes Brachydactyly mental retardation syndrome, a disorder characterized by severe learning and memory deficits [78]. These studies and findings suggest that different HDACs act as crucial positive and negative regulators of learning and memory. As such, use of non-specific pharmacological HDAC inhibitors should be approached cautiously.

\section{RNAs that regulate chromatin}

In addition to histone modifications and DNA methylation, a further layer of epigenetic regulation exists at the level of RNA-mediated establishment and regulation of chromatin states. The first evidence of RNA-influenced chromatin modification in mouse was that of the X-inactive specific transcript (Xist) long-noncoding RNA [79, 80]. In placental mammals, female $X X$ cells express the Xist transcript from the inactive $\mathrm{X}$ chromosome, leading to multiple copies of the transcript coating the chromosome in cis [81]. The Xist transcripts bind to and recruit the heterochromatin-forming PRC2 [82] and YY1 protein, silencing the inactive $\mathrm{X}$ chromosome [83]. Other long-noncoding RNAs have been shown to regulate chromatin in a similar manner. For example, the HOX transcript antisense RNA (HOTAIR) serves as a scaffolding molecule between the PRC2 complex and LSD1-CoREST complex [84]. By coupling these complexes, there can be a targeted simultaneous removal of active H3K4me by LSD1 and deposition of repressive H3K27me, serving as an epigenetic switch from on to off. Additionally, Piwiinteracting RNAs (piRNAs), short RNAs that interact with the PIWI family of proteins, are thought to specifically target transposon sites in the germline in order to facilitate silencing [85]. In all of these cases, a noncoding RNA serves as a trigger or guide for other molecules in the maintenance of the chromatin, adding another layer of complex epigenetic regulation.

Together, many different facets of epigenetic regulation dynamically influence the state of chromatin, fine-tuning transcriptional programs that establish different cell fates (Fig. 1). During neuronal development and in mature neurons, it is increasingly clear that defects in these epigenetic mechanisms underlie neural disease. Below, we highlight three specific emerging examples of these mechanisms.

\section{MeCP2 regulates long gene expression in neurons}

One protein that plays a role in epigenetic-mediated neurological disease is the $\mathrm{X}$-linked methyl-CpG-binding protein 2 (MeCP2). It was first identified in an assay for proteins that bind methylated DNA, where it showed a much higher affinity for oligonucleotides containing methylated cytosine than the previously described MeCP1 [86]. While MeCP1 required at least 12 methylated cytosines per oligonucleotide for recognition, MeCP2 demonstrated binding capabilities with just a 

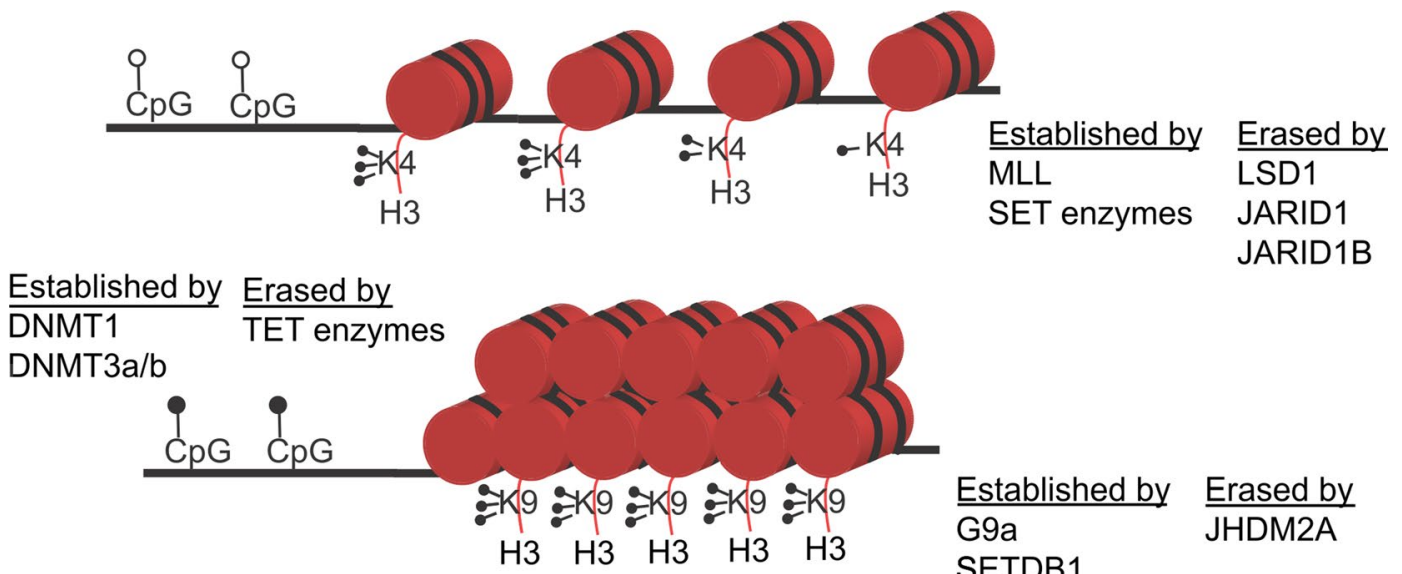

\section{Established by G9a SETDB1} SUV39H1

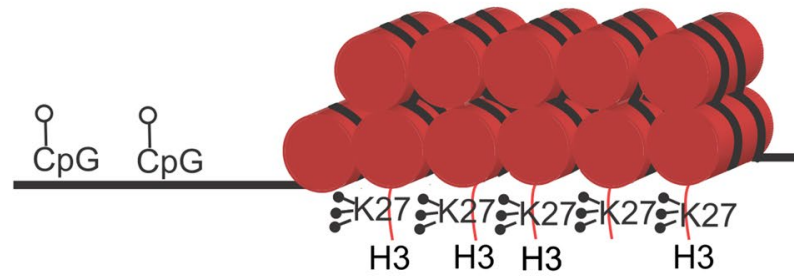

Fig. 1 Chromatin modifications and their associated factors. Transcriptionally permissive chromatin is associated with the absence of DNA methylation (open lollipops) and the presence of H3K4me3/2/1. This mark is established by the MLL and SET family of enzymes and is found in genes actively undergoing transcription. $\mathrm{H} 3 \mathrm{~K} 4 \mathrm{me} 3$ is found in the promoters, $\mathrm{H} 3 \mathrm{~K} 4 \mathrm{me} 2$ is found in gene bodies, and H3K4me1 is found in the enhancers of active genes. These marks are erased by demethylases such as LSD1, JARID1, and JARID1b. Transcriptionally repressive chromatin features concurrent cytosine methylation (closed lollipops) and H3K9me3. Cytosine methylation is established by the DNA methyltransferases and erased by the TET family of enzymes. H3K9me3 is established by G9a, SUV39H1, and SETDB1 and erased by JHDM2A. Alternatively, transcriptionally repressive chromatin can contain H3K27me3 and no cytosine methylation (open lollipops). H3K27me3 is established by EZH2, part of the polycomb repressive complex, and is erased by JMJD3 and UTX

single, symmetrically methylated CpG site. Given the long-standing theory that site-specific DNA methylation is a transcriptionally repressive mark, it was immediately speculated that MeCP2 acts as a transcriptional repressor by binding methylated CpGs to inhibit transcription [86]. Indeed, in vitro, $\mathrm{MeCP} 2$ was found to repress transcription of reporter genes in a methyl-DNA-dependent manner through its association with Sin3a, a transcriptional repressor, and histone deacetylases (HDACs), which facilitate chromatin compaction [87-89]. Transcriptional repression associated with $\mathrm{MeCP} 2$ is relieved by treatment with the HDAC inhibitor trichostatin A, suggesting that MeCP2-mediated HDAC recruitment to methylated DNA is a critical step in MeCP2-mediated repression [90].

MeCP2 is ubiquitously expressed throughout all human and mouse tissues, but is most highly abundant in the brain. In neurons, its expression levels are comparable to histone octamers in adult animals [91]. Within the central nervous system, MeCP2 is expressed at low levels during neurogenesis, but gradually increases during neuronal maturation and synaptogenesis, reaching peak expression in mature, post-migratory neurons. This suggested a potential role for MeCP2 in the maintenance of neuronal maturation, activity, and plasticity [92-94]. Loss-of-function mutations in MeCP2 are the cause of Rett syndrome (RTT) [95], a devastating neurological disorder. As MeCP2 is an X-linked gene, RTT primarily affects females, since males with loss-of-function mutations in MeCP2 typically die in utero or perinatally [96]. Following a period of seemingly normal development during the first 6-18 months of life, RTT patients undergo a period of developmental stagnation followed by rapid, progressive motor deterioration and neurological regression. Patients also display a characteristic hand wringing and autism spectrum-like behavior. The onset of symptoms in RTT patients occurs at the same developmental timepoint that $\mathrm{MeCP} 2$ expression normally increases in the unafflicted brain. Despite decades of intense research on $\mathrm{MeCP} 2$, there is still no clear mechanism as to how MeCP2 dysfunction could lead to RTT; however, patient mutations tend to cluster in the methyl 
binding domain and transcriptional repressor domains of $\mathrm{MeCP} 2$, suggesting that transcriptional repression is inhibited in patients [97].

Intriguingly, the developmentally regulated increase in MeCP2 expression within the CNS also coincides with the acquisition of $5 \mathrm{mCH}$ in neurons. Indeed, in addition to its interaction with methylated $\mathrm{CpG}$ residues, $\mathrm{MeCP} 2$ has been reported to regulate gene transcription through its capacity to bind methylated CA dinucleotides (5mCA) in vitro and in mouse brain [16, 39, 98, 99]. Recently, Gabel et al. [100] described a mechanism by which neurons regulate the expression of very long genes (e.g., $>100 \mathrm{~kb}$ ) in a MeCP2- and 5mCA-dependent mechanism. Specifically, they found that in brains of RTT patients and in mouse models of RTT, there is a genome-wide lengthdependent increase in gene expression. The authors further show that MeCP2 binds 5mCA with high affinity and that MeCP2 binding is enriched in gene bodies with a high level of $5 \mathrm{mCA}$, suggesting that $\mathrm{MeCP} 2$ binds $5 \mathrm{mCA}$ residues to repress transcription (Fig. 2). Notably, long genes that contain high levels of $5 \mathrm{mCA}$ are highly associated with neuronal processes, raising the possibility that their expression must be tightly regulated in neurons by MeCP2. Consistent with this model, disruption of Dnmt3a leads to a length-dependent increase in expression of these genes, presumably through loss of $5 \mathrm{mCA}$. This role for MeCP2 as a regulator of long genes appears to be a neuron-specific phenomenon, as other tissues do not display this misregulation of long gene expression. This work suggests that MeCP2 tempers the expression of neuronal-specific long genes to prevent their overexpression, which could disrupt neuronal physiology [100].

Given the pattern of gene body $5 \mathrm{mCH}$ in neurons [16, 41] and the role for MeCP2-mediated repression of long genes [100], the Greenberg Lab has proposed a novel hypothesis to address the underlying cause of RTT pathology: as neurodevelopment takes place, neuronal subtypes are specified, and gene body $5 \mathrm{mCA}$ is acquired at genes where expression either needs to be repressed or tightly regulated. Normally, this gene body methylation is written by DNMT3a and read by MeCP2 and associated factors. However, in the absence of $\mathrm{MeCP} 2$, this finely tuned regulation is lost and derepression of neuronal genes occurs. In this model, perturbation of DNMT3a could lead to aberrant $5 \mathrm{mCA}$, and thus altered $\mathrm{MeCP} 2$ binding, and may itself lead to neurological dysfunction. In both scenarios, loss of regulation mediated by DNA methylation can then lead to inappropriate transcriptional regulation of neuronal genes, causing neuronal dysfunction and severe autism-like phenotypes. Notably, disruption of DNMT3A has recently been reported as the underlying cause of the neurodevelopmental disorder Tatton-Brown-Rahman syndrome [101], and mutations in DNMT3A have been identified in individuals diagnosed with autism spectrum disorders [102]. Thus, disruption of gene regulation by $5 \mathrm{mCA}$ may

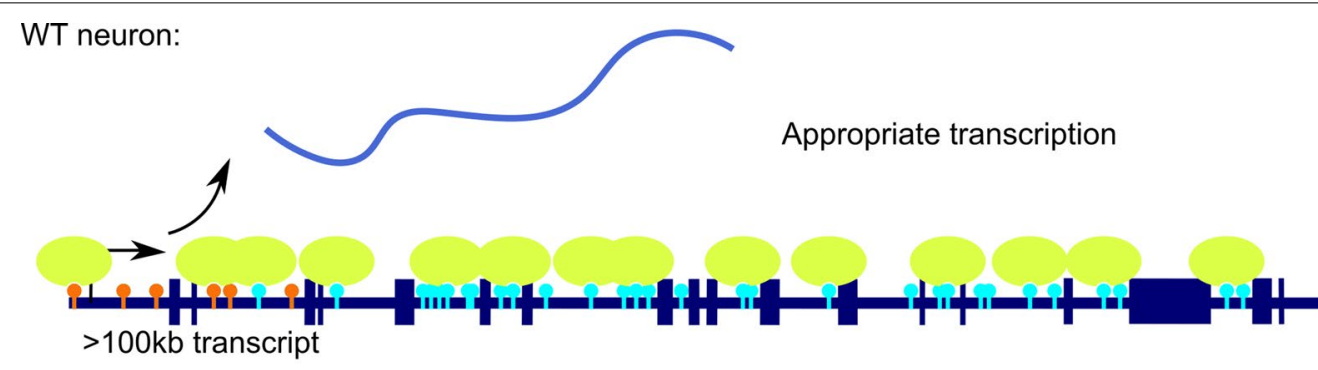

$5 \mathrm{mCG}$ $5 \mathrm{mCA}$

Mecp2 null neuron:

$\mathrm{MeCP} 2$

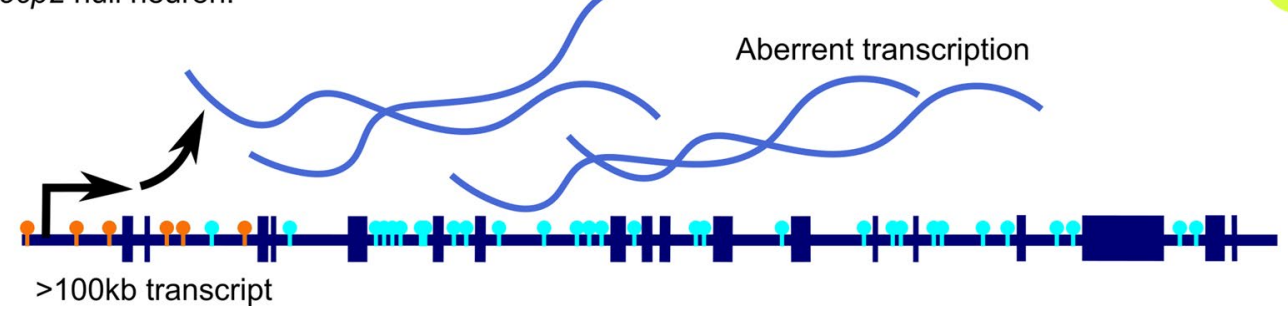

Fig. 2 MeCP2 regulates long gene expression in a 5mCA-dependent manner. The $5 \mathrm{mCG}$ mark is commonly found enriched at gene promotor regions, while the $5 \mathrm{mCA}$ mark is enriched in the gene bodies of exceptionally long genes (>100 kb) in neurons. The epigenetic "reader" MeCP2 binds both marks, but has a strong affinity for $5 \mathrm{mCA}$ in long gene bodies. In wild-type neurons, this interaction represses transcription of long genes and may allow for fine tuning of gene expression. Currently, the machinery and mechanism by which MeCP2 silences long genes is unknown. In the Mecp2 null neuron, 5mCA marks in long genes go unrecognized and the locus is aberrantly transcribed 
be a common site of disruption across neurodevelopmental disorders.

\section{FMR1 mRNA induces epigenetic silencing of the locus}

A role for RNA-mediated epigenetic regulation and DNA methylation-dependent silencing in neurological disease can be found in Fragile X syndrome (FXS), the most common form of inherited intellectual disability. FXS patients have characteristic IQ scores below 70 and are commonly on the autism spectrum [103]. The disease is named for the appearance of bent $\mathrm{X}$ chromosomes on karyotypes of patients. This bend takes place at the Fragile X mental retardation 1 locus (FMR1), and the subsequent silencing of this locus causes FXS [104]. The disease is most often observed in males because they are hemizygous for the gene and are therefore susceptible to mutations in their single allele. The protein encoded by the FMR1 gene is Fragile X mental retardation protein (FMRP), an RNA binding protein that is proposed to tightly regulate local translation in neurons by inhibiting translation presynaptically $[105,106]$. The etiology of the disease is thought to stem from an epigenetic silencing of the locus and consequential loss of the FMRP protein, increasing protein translation at synapses [107-110]. The FMR1 locus features a CGG trinucleotide repeat in the $5^{\prime} \mathrm{UTR}$, adjacent to the promoter. Individuals with 5-40 repeats are considered normal, while those with greater than 200 repeats develop FXS [111]. Those with 40-200 repeats are classified as having a premutation for the disease. Interestingly, a subset of these individuals develops a late-life gait ataxia and intention tremor known as Fragile X-associated tremor/ataxia syndrome (FXTAS) [112]. In contrast with those with the full mutation, FXTAS patients appear to have an overabundance of Fmr1 transcripts [113]. It is unclear why premutation repeats escape silencing in favor of increased expression and how exactly this leads to the condition, but there is a clear toxicity due to overexpression of the Fmr1 gene. This contrast with FXS, where the transcript is silenced, demonstrates the sensitivity of neurons to the dosage of the Fmrl gene and the complex epigenetic mechanisms that regulate the locus.

It was hypothesized that the $\mathrm{CPG}$ dinucleotide within the CGG repeat underlies the cause of FXS as CpG methylation could play a role in the silencing of the locus. Human embryonic stem cells with $>200$ CGG repeats express Fmrl in their undifferentiated state and lack chromatin modifications associated with silencing at the genetic locus. However, similar to what is observed in FXS embryos, when the cells are cultured under differentiation conditions, there is a downregulation of the transcript, acquisition of CpG DNA methylation, loss of
H3K9 acetylation, and gain in H3K9 methylation at the Fmr1 locus (Fig. 3) [114].

The factors that trigger silencing of the Fmr1 locus were unknown until recent work from Jaffary and colleagues suggested that the Fmrl mRNA may initiate silencing of the locus [115]. Human embryonic stem cells ( $\mathrm{hESC}$ ) derived from FXS patients with a CGG expansion of at least 200 repeats display Fmr1 expression comparable to undifferentiated control cells, but the transcript is silenced when the hESC are differentiated into neurons. During silencing, H3K4me2 is lost and H3K9me2 is gained at the Fmr1 locus. Knockdown of the FMR1 transcript during differentiation prevented the acquisition of heterochromatin marks at the locus, suggesting the transcript itself may be necessary for the induction of heterochromatic silencing. The authors hypothesized that the CGG repeat in the transcript binds to the DNA to form a heteroduplex. Using chromatin isolation by RNA purification (ChIRP), which uses biotinylated oligonucleotides to immunoprecipitate RNA bound to chromatin, the authors showed that the Fmr1 transcript binds to the Fmr1 locus prior to heterochromatic silencing specifically in FXS cell lines. This interaction is most enriched when oligonucleotides are tiled next to the trinucleotide repeat of the transcript and when primer pairs closest to the trinucleotide repeat on the chromosome are used to amplify the precipitated DNA. This suggests the anchor point of the interaction takes place between the repeat regions of the DNA and RNA. Furthermore, the interaction is seemingly independent of protein intermediates and is abolished when treated with RNaseH, which selectively degrades RNA-DNA heteroduplexes. These data suggest that the trinucleotide repeat in the $5^{\prime}$-UTR of the transcript binds to the trinucleotide repeat of the DNA prior to the heterochromatic silencing of the Fmr1 gene and leads to its silencing [115]. Future studies will likely focus on uncovering the machinery that responds to this RNA-DNA interaction to silence the locus and whether abolishing this interaction could be a therapeutic target.

\section{REST in neurodegenerative diseases}

Alzheimer's disease (AD) is the most common form of dementia worldwide, accounting for about $60-70 \%$ of cases [116]. Patients present with memory loss, disorientation, language defects, and behavioral changes and require years of care following cognitive decline. $\mathrm{AD}$ is characterized by a global reduction in brain mass during the course of the disease, primarily driven by loss of synaptic connectivity and neuronal processes. In addition, there is neuronal loss that begins in the excitatory neurons of the entorhinal cortex and moves to the dentate gyrus, $\mathrm{CA} 3$, and $\mathrm{CA} 1$ regions of the hippocampus, ultimately becoming widespread in many cases. Loss of 

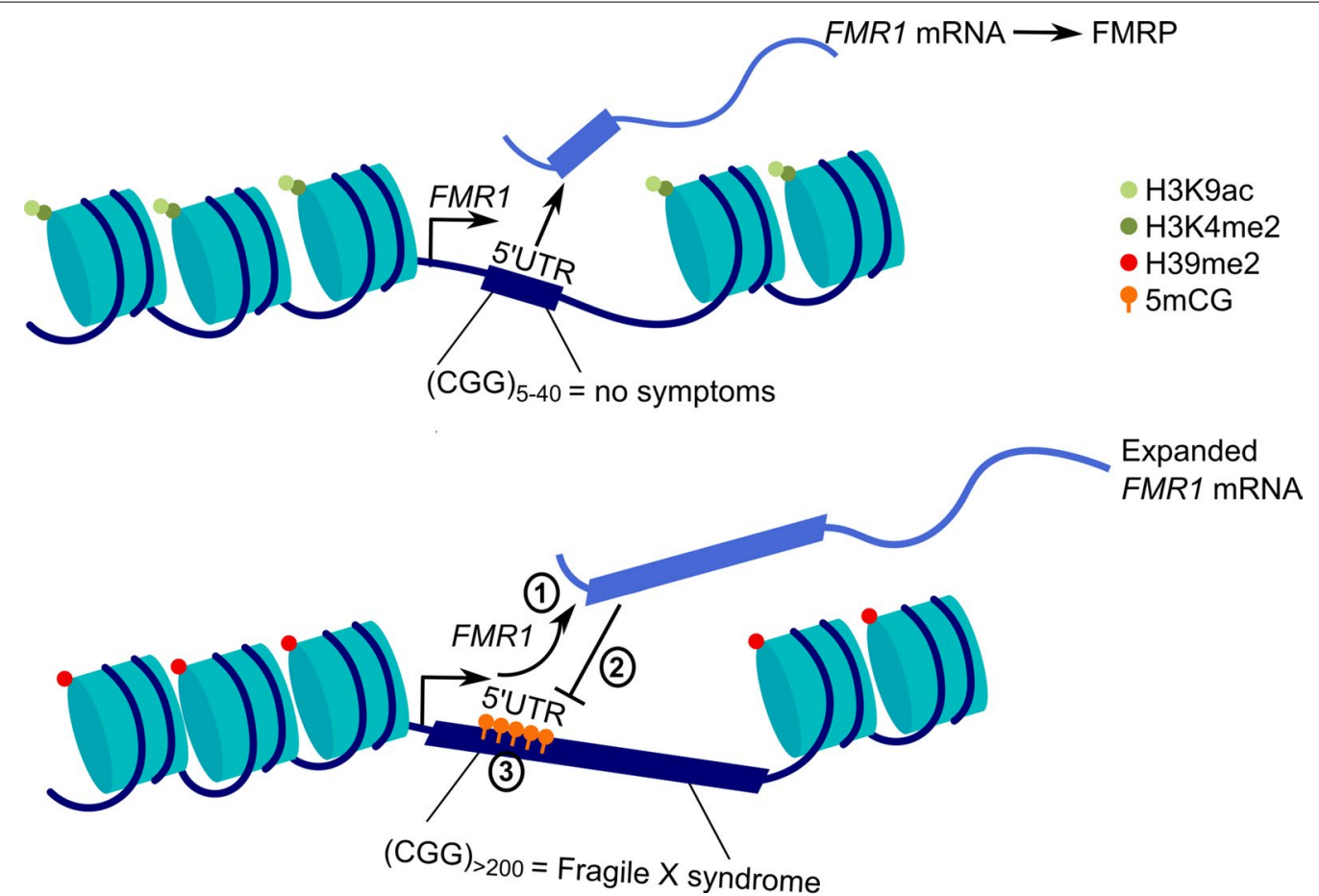

Fig. 3 Expanded FMR1 mRNA silences the FMR1 locus through an epigenetic mechanism. The FMR1 locus features a CGG trinucleotide repeat in the 5'UTR of the gene. Typically, the trinucleotide is repeated 5-40 times; however, expansion of this site to >200 repeats causes Fragile X syndrome. The trinucleotide repeat in the resulting expanded FMR1 mRNA transcript (1) binds to its CGG expansion at the DNA locus to form a heteroduplex. Through an unknown mechanism, this interaction silences transcription from the FMR1 locus (2). The locus then acquires a repressive chromatin state. Specifically, active histone marks H3K9ac and H3K4me2 are removed, while repressive mCG and H3K9me2 marks are added (3)

synaptic connectivity has a greater correlation with cognitive decline than neuronal loss, suggesting it may play a greater role in the progression of $\mathrm{AD}$ [117]. In addition, improper neural network activity, hippocampal hyperactivity, and reduced hippocampal volume have been observed $[118,119]$. Together, the combination of neuronal loss, neuronal hyperactivity and synaptic loss leads to cognitive dysfunction, resulting in the dementia phenotype.

During the course of the disease, there is an accumulation of pathological protein aggregates in the brain. Two distinct structures occur: senile plaques containing amyloid beta $(A \beta)$ and hyperphosphorylated Tau containing neurofibrillary tangles $[120,121]$. A $\beta$ plaques are composed of a peptide derived from amyloid precursor protein (APP), a constitutively expressed transmembrane protein found in many cell types [122]. As part of normal neuron physiology, APP is cleaved by a series of secretases, $\alpha$-secretase, $\beta$-secretase (BACE), and $\gamma$-secretase (Presenilin 1 and 2) [123-125]. Cleavage by BACE, then by the Presenilins, results in the 42 amino acid peptide product (A $\beta 42)$ [126]. A $\beta 42$ occurs normally but also has a propensity to aggregate. Over decades, this leads to the formation of amyloid plaques.
Unsurprisingly, mutations in this processing pathway are associated with familial forms of AD [127, 128]. In these cases, affected individuals develop early-onset $A D$, presumably due to a shift in APP cleavage that produces more $A \beta 42$. However, in contrast, some healthy elderly individuals have buildups of protein aggregates, but do not show signs of cognitive impairment, suggesting that these aggregates are not entirely sufficient to cause neurodegeneration [129]. These observations exemplify the uncertainty surrounding the contribution of $A \beta$ plaques to $\mathrm{AD}$ pathology.

Pathological aggregates of the microtubule-associated protein Tau are also highly correlated with AD [130]. Tau is normally found in the dendrites of neurons and facilitates the polymerization of microtubules. However, Tau protein can become hyperphosphorylated and acetylated resulting in aggregation of the protein into filamentous neurofibrillary tangles (NFTs) [131-133]. Formation of NFTs is thought to occur secondarily to accumulation of $A \beta$, as mutations in APP and Presenilins are sufficient to induce formation of both $A \beta$ plaques and NFTs [134]. However, Tau aggregation in demented brains has a higher correlation with cognitive decline than the presence of $A \beta$ plaques, suggesting Tau burden could be 
more tightly linked to the pathogenicity of the disease [130]. NFTs accumulate intracellularly and were originally thought to contribute to the disease by reducing the available pool of Tau to perform its normal function with microtubules, thereby disrupting cytoskeletal physiology [135]. This view has recently been challenged by two findings. First, loss-of-function mutations in Tau cause no gross abnormalities in mice [136]. Second, pathogenic hyperphosphorylated Tau accumulates in dendrites and can disrupt synaptic transmission [137-140]. These results raise the possibility that pathological aggregates of Tau could disrupt neurons by interfering with the function of other proteins.

Despite our understanding of which molecules aggregate and how it occurs, there is still a gap in understanding of how these aggregates cause neuronal cell death. Numerous models for the connection between protein aggregates and neuronal cell death have been suggested, including neuroinflammation mediated by microglia and the complement cascade [141, 142], cell cycle reactivation and DNA replication [143], nuclear pore instability [144], and loss of mitochondria coupled to the generation of reactive oxygen species [145]. Additionally, there have been several attempts to identify other agents using genetic approaches. One such gene with associations to $\mathrm{AD}$ is ApoE. ApoE is an apolipoprotein with three major allelic isoforms: $\varepsilon 2, \varepsilon 3$, and $\varepsilon 4$. The isoforms arise from single amino acid substitutions. Individuals homozygous for the ApoE4 allele have a greater than $90 \%$ chance of developing late-onset AD [146]. This high incidence of $\mathrm{AD}$ in individuals with the mutation strongly suggests the ApoE protein has a role in the development of the disease; however, no clear role has yet been defined. Despite these clear genetic links with $\mathrm{AD}$, identified genetic associations account for only a small fraction of susceptibility to $\mathrm{AD}$, suggesting that other factors also contribute to the development of AD [147].

The RE1-silencing transcription factor (REST) was recently shown to be neuroprotective and aberrantly associated with protein aggregates during the course of neurodegenerative diseases. Thus, REST could be part of the missing piece in the AD puzzle [148]. REST, also known as neural restrictive silencing factor (NRSF), is a repressive transcription factor that binds to the canonical RE-1 recognition motif sequence and with the help of a set of corepressors silences transcription of neuronal genes in non-neuronal lineages $[149,150]$. This silencing is achieved through the recruitment of HDACs and repressive histone methyltransferases, such as G9a the H3K9 methyltransferase [151]. Other corepressors that have been reported to associate with REST include CoREST, LSD1, MeCP2, and the C-terminal binding protein (CtBP) [152, 153]. Despite its status as a master negative regulator of the neuronal cell fate, REST is expressed at low levels in differentiated neurons, suggesting that it may still play a role in adult neurons.

The role of REST in adults is largely unexplored. However, Yankner and colleagues recently showed that REST expression is reactivated in healthy aging human neurons and gains neuroprotective properties by binding to and repressing apoptotic genes [148]. In mice, the authors showed that REST deficiency causes slight age-related neurodegeneration. In addition, mutants in $s p r-4$, the $C$. elegans orthologue of the mammalian REST, were found to be more susceptible to oxidative stress and $A \beta$ toxicity, further demonstrating the conserved neuroprotective qualities of REST. Yankner and colleagues also provided evidence that REST protein may be sequestered away from neuronal nuclei into autophagosomes along with protein aggregates that develop during the course of the disease in human brains derived from $A D$, frontotemporal dementia (FTD), and Lewy body dementia (LBD) cases. When REST protein is absent from the nucleus, there is an increase in global H3K9 acetylation levels, suggesting that epigenetic derepression occurs in the absence of REST. The degree of sequestration outside of the nucleus correlates with the severity of the cognitive impairment of the patient. These findings suggest that pathological $A \beta$ protein aggregates may cause the mislocalization of REST, leading to the loss of its neuroprotective properties and normal epigenetic regulation. In the absence of REST protein, pro-apoptotic REST targets could be inappropriately expressed and lead to neuronal cell death by activating apoptosis pathways. Presumably, in the absence of nuclear REST, other corepressors dependent upon REST for targeting to specific loci may also be mistargeted, resulting in further misexpression. This cascade of aberrant transcriptional regulation may explain the large number of loci that become dysregulated in REST mutants.

\section{LSD1 is an epigenetic eraser and regulator of cell fate transition}

As discussed earlier in this review, histone methylation can be reversed by histone demethylases, allowing the histone mark to serve as a dynamic regulator of transcription. The histone demethylase LSD1 specifically demethylates mono- and dimethylation of lysine 4 on histone H3 (H3K4me1/2) marks [51, 154] and requires the corepressor CoREST to demethylate H3K4 in the context of a nucleosome [155]. By demethylating H3K4, LSD1 acts as a transcriptional repressor by removing an active modification. Alternatively, when associated with the androgen receptor complex, LSD1 has been shown to demethylate H3K9me2 [156], allowing it to also serve as a transcriptional activator by removing a repressive mark. 
The most studied role for LSD1 is as a facilitator of cell fate transitions. The mutants in the $C$. elegans LSD1 orthologue spr-5 exhibit transgenerational progressive sterility over the course of 30 generations. This sterility is thought to arise from the accumulation of $\mathrm{H} 3 \mathrm{~K} 4 \mathrm{me} 2$ in spermatogenesis genes, causing inappropriate expression of sperm genes in oocytes [157]. This role has led to the proposal that H3K4me2 acts as an epigenetic memory of transcription, and its passage through the germline can influence gene expression in offspring. A similar sterility phenotype has also been observed in Drosophila mutants for $L s d 1$, although sterility occurs in the first generation [158-160]. The function of LSD1 in regulating H3K4me2 is conserved in mice. Deletion of LSD1 from the female oocyte alone results in embryos arresting at the one- or two-cell stage. Arrested embryos feature altered DNA methylation patterns and failure to undergo the maternal-to-zygotic transcriptional transition [161, 162]. Together, these observations suggest that LSD1 functions in the reprogramming of epigenetic information between generations, likely by demethylating histones in the early zygote and preventing the passage of epigenetic cell fate information from one generation to the next.

LSD1 is also necessary for proper differentiation of mouse embryonic stem cells (mESCs) [163]. LSD1 binds to promoters and enhancers of critical embryonic stem cell genes in (mESCs), but does not actively demethylate the H3K4 methylation associated with these loci until the mESCs undergo differentiation. At this point, LSD1 erases the H3K4 methylation associated with these loci in coordination with the nucleosome remodeling and deacetylase complex (NuRD complex), which contains HDAC1 and 2, as well as the ATPase remodeler Mi-2 $\beta$. When mESCs are differentiated in the presence of an LSD1 inhibitor, there is an inappropriate retention of critical stem cell gene expression and associated H3K4 methylation at both the enhancers and promoters of these loci. This suggests that LSD1 is responsible for the demethylation of $\mathrm{H} 3 \mathrm{~K} 4$ methylation at stem cell genes during mESC differentiation, which enables proper repression of mESC-specific loci [163]. As such, LSD1 regulates the cell fate transition of mESCs. A similar model has been proposed in murine hematopoietic stem cells [164].

The requirement of LSD1 to facilitate cell fate transitions is highly critical to many developmental processes. Consistent with this, depletion of LSD1 causes severe phenotypes in mice. Lsd1 homozygous null mice arrest at embryonic day 5.5 and fail to properly elongate the egg cylinder before being resorbed by embryonic day 7.5 $[165,166]$. In addition, loss of LSD1 in specific cell types causes a wide range of phenotypes. LSD1 depletion in the developing telencephalon causes defects in olfactory receptor choices. Mutation of a critical LSD1 phosphorylation site alters murine circadian rhythm. In vitro, researchers observe that LSD1 knockdown causes defects in plasma cell and hematopoietic cell differentiation; in vivo, deletion of $L s d 1$ in pituitary tissue, testis stem cells, and trophoblast stem cells leads to differentiation defects. In addition, transgenic mice overexpressing LSD1 exhibit increased oxidative phosphorylation and fat, as well as paternally inherited transgenerational effects [162, 164, 165, 167-175].

\section{LSD1 promotes neural differentiation}

Multiple lines of evidence also suggest an important role for LSD1 in neural differentiation. The LSD1/CoREST complex acts as a potent mediator of pyramidal neuron development by orchestrating radial migration. Inhibition of the LSD1/CoREST complex in embryonic mice results in a dramatic reduction of neural migration, causing newborn neurons to linger in the ventricular zone and subventricular zone for a longer period of time while retaining a multipolar shape characteristic of intermediate progenitor cells. This LSD1/CoREST-mediated migratory pathway appears to occur independently of REST activity [176].

Recently, a neuronal-specific isoform of LSD1 (LSD1n), which contains the additional exon 8a, has been implicated in regulation of neuronal differentiation. Specifically, this isoform demethylates the repressive H3K9me2 mark with its binding partner supervillin (SVIL) to activate expression of neuronal-specific genes during differentiation. Knockdown or mutation of the LSD1n isoform during induced in vitro differentiation decreases neurite outgrowth, while overexpression of intact LSD1n increased neurite outgrowth (Fig. 4a) [177, 178]. This neuronal isoform has also been shown to demethylate the repressive mark $\mathrm{H} 4 \mathrm{~K} 20 \mathrm{me} 2$, activating transcription by promoting transcriptional initiation and elongation in response to neurotransmission [179]. In addition, LSD1n deficient mice display cognitive deficits and impaired spatial learning.

Maternal deposition of LSD1 in the developing oocyte adds yet another layer of complexity to the role of LSD1 in neural development. Partial loss of maternally loaded LSD1 causes in a hypomorphic phenotype in the resulting embryo. The few animals that survive the absence of maternal display developmental defects and behavioral abnormalities reminiscent of autistic-like phenotypes [162]. These findings for a role of LSD1 in neurodevelopment are bolstered by the recent discovery of three human patients with mutations in the $L s d 1$ gene that display neurodevelopmental delay and intellectual disability [180]. 


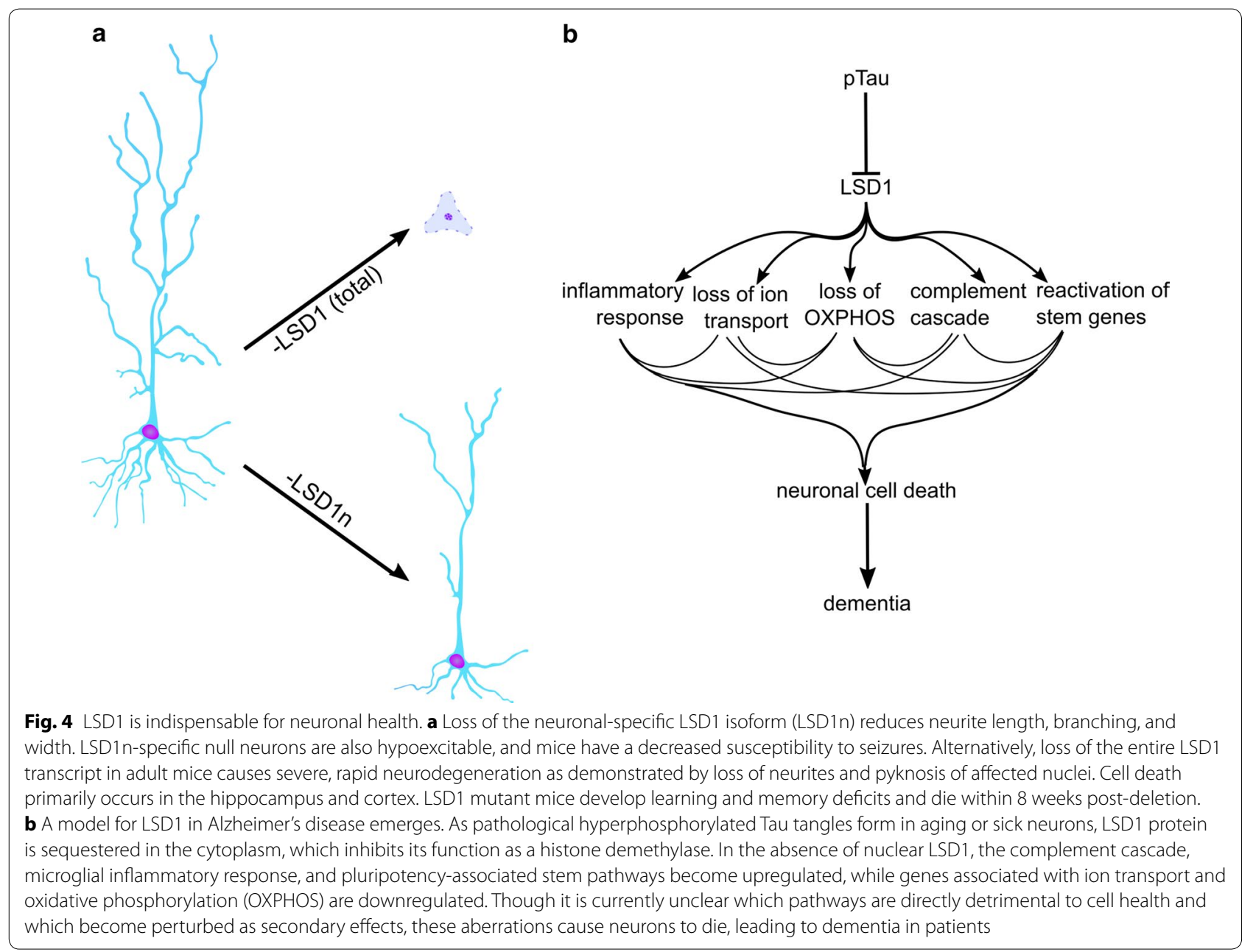

\section{LSD1 is required for adult neuronal survival}

Although LSD1 plays a clear role as a facilitator of cell fate transitions, little is known about the requirement for LSD1 in differentiated cell types. The importance of understanding this novel role has been emphasized by our recent discovery that LSD1 is required for neuronal survival and maintenance of adult, post-mitotic neuronal identity [181]. To assay its function in adult neurons, we deleted $L s d 1$ using a tamoxifen-inducible CAGGCre (hereafter referred to as $L s d 1^{C A G G}$ ) in mice ranging from 2 to 6 months of age. Four weeks after Lsd1 deletion, mutant mice have significantly reduced spatial learning, poor reference memory capacity, and impaired contextual fear conditioning. Approximately 7 weeks after tamoxifen injection, $L s d 1^{C A G G}$ mice undergo severe, rapid neuronal cell death, which primarily affects the hippocampus and cerebral cortex (Fig. 4a). At this point, mutant mice have severe motor deficits including lethargy, limb weakness and clasping, and the inability to maintain posture. Despite these severe motor phenotypes, the peripheral nervous system does not appear to be affected by CAGG-mediated Lsd 1 deletion. By 8 weeks post-injection, mutant mice are severely paralyzed and moribund, while most hippocampal neurons appear pyknotic. LSD1 protein is still present in neurons up to 7 weeks post-injection, despite a full deletion of the locus within $24 \mathrm{~h}$ [181]. The persistence of LSD1 in induced genetic nulls could be due to a very stable mRNA, a long protein half-life, or both. This finding indicates that the absence of LSD1 protein induces neuronal cell death very rapidly, over the span of just 1 week. Furthermore, mice are sensitive to very small fluctuations in LSD1, since we observe learning and memory deficits as early as 4 weeks post-injection.

Why would an epigenetic factor that orchestrates cell fate transition be required in terminally differentiated neurons? To address this paradox, we examined how loss of LSD1 affects neuronal homeostasis. RNAseq and immunohistochemistry (IHC) in LSD1-deficient hippocampus revealed an upregulation of several 
pluripotency transcripts, including Foxo1, Klf4, Oct4 and $M y c$. This upregulation of pluripotency transcripts is accompanied by a reactivation of cell cycle markers. Through IHC, we determined that these pathways are upregulated specifically in neurons. Thus, it appears that LSD1 contributes to actively maintaining the differentiated state of neurons by preventing the inappropriate expression of genes associated with other cell fates. Remarkably this data hints that neurons are not "locked" into their cell fate. Instead they must continually employ epigenetics mechanisms to actively maintain their differentiated cell fate.

Prior to our study, LSD1 had never before been implicated in neurodegenerative disease. However, we observed a specific correlation between the $L s d 1^{\text {CAGG }}$ hippocampus transcriptional profiles and those observed in human late-onset Alzheimer's disease (LOAD) and frontotemporal dementia (FTD) [142, 182]. Specifically, without LSD1 in hippocampal neurons, there is an upregulation of the complement cascade pathway, as well as the microglia and immune transcriptional network. In addition, genes involved in neurotransmission and oxidative phosphorylation are downregulated. These pathways are similarly perturbed in LOAD and FTD patients. Beyond the individual neurodegeneration pathways, the transcriptional changes in $L s d 1^{C A G G}$ hippocampus highly correlate with the transcriptional changes in the prefrontal cortex of AD and FTD patients genome wide.

Given the striking neurodegenerative phenotype and transcriptional overlap with human dementias, we hypothesized that LSD1 might be affected in these neurodegenerative diseases. In human LOAD and FTD cases, we find that $L S D 1$ mislocalizes with pathological Tau aggregates in AD and TDP-43 aggregates in FTD. These findings suggest a new model for these diseases: as the pathological proteins pTau (in AD), or TDP-43 (in FTD), accumulate in aging neurons, $L S D 1$, normally localized to the nucleus, becomes sequestered by these protein aggregates in the cytoplasm. Its mislocalization interferes with the neuron's ability to epigenetically maintain its cell fate by blocking inappropriate transcription, and this inappropriate transcription ultimately leads to the activation of multiple neurodegeneration pathways (Fig. 4b).

Much more work is needed to understand the etiology of LSD1-mediated neurodegeneration. For example, it's currently unclear if LSD1-deficient neurons die from necrosis, apoptosis, or engulfment in a microglia response pathway. Would inhibiting these pathways prevent cell death in Lsd1 mutant mice? Understanding the mechanism of neuronal death in these animals is the first step toward blocking death. These data also raise the question of why neurons appear to be the cell type most sensitive to LSD1 loss. The study of LSD1 as an epigenetic regulator in the healthy adult brain will help us understand its pivotal role in this cell type. Further, we present for the first time a novel potential therapeutic pathway for targeting $\mathrm{AD}$ progression. Could we harness the LSD1 pathway and suppress tauopathy-related phenotypes by inhibiting LSD1 sequestration to the cytoplasm? Could the consequences of pathology be reversed if LSD1 was redirected to the nucleus or if LSD1 gene targets could be pharmacologically repressed?

Presently, our understanding of epigenetics in neurodegeneration is rapidly expanding. As mentioned previously, the role of REST in the aging brain illuminates another pathway, in addition to LSD1, by which epigenetic modification maintains neuronal health. REST can interact with the CoREST complex, which contains LSD1, so it is possible that LSD1 and REST function together. However, despite the similarities in pathological mechanism, we believe that aberrations in the REST and LSD1 pathways occur independently and operate separately in the aging brain. For example, in AD, REST associates with $A \beta$ in autophagosomes, while LSD1 localizes to NFTs of hyperphosphorylated Tau. Also, the reported REST neurodegeneration phenotype in mice is much less severe than what we observe in our LSD1 mutants, suggesting at a minimum that their functions do not completely overlap.

Many other epigenetic modifications have been implicated in AD and other tauopathies. For example, the APP promoter is hypomethylated in $\mathrm{AD}$, though the overall methylation status of the AD genome is debated [183, 184]. Defects in epigenetic silencing in the presence of pTau have also been reported. Specifically, overexpression of mutant human Tau, associated with familial cases of FTD, results in loss of heterochromatin in Drosophila and mouse. Additionally, neurons containing NFTs display significant loss of heterochromatin in human $\mathrm{AD}$ and FTD cases [185]. This suggests that epigenetic factors that promote heterochromatin formation could be impaired in the presence of NFTs. Currently, it's not well understood whether these findings indicate the cause or the effect of the disease state. Untangling the two is particularly difficult, since epigenetic modifications regulate a host of downstream gene networks. However, the manipulation of epigenetic pathways in neurodegenerative models will begin to inform on these possibilities and illuminate new therapeutic targets.

\section{Conclusions}

Though originally thought to be relatively stable, epigenetic modifications are capable of dynamic change, providing the perfect medium by which a post-mitotic neuron can respond to changes. For example, alterations 
in the DNA methylation across the life of a neuron can bolster plasticity or fine-tune a response to a signaling cascade. As a result, the DNA methylation landscape has quickly emerged as a major player in regulating neuronal gene expression. However, as illustrated above, deviations in DNA methylation can severely hinder neuronal health. Without maintenance from the DNMT proteins, DNA methylation can be completely lost at some gene promoters, altering the transcription of the locus. Alternatively, mutation in $\mathrm{MeCP} 2$, the reader of DNA methylation, can change the transcriptional profile of the neuron, severely hindering its plasticity and vitality. In addition, changes in DNA methylation at the FMR1 locus may underlie the etiology of FXS, as the FMR1 transcript acts in cis to alter the histone modification profile and increase CpG methylation at its own locus.

As evidenced by the action of both REST and LSD1, histone modifications may also have a profound effect on gene regulation in post-mitotic neurons. Loss of either of these epigenetic factors is detrimental to the health of adult neurons and induces a cascade of transcriptional changes. Further, deletion of LSD1 from post-mitotic neurons causes the cells to undergo rapid neurite degeneration and death. Curiously, before they degenerate, LSD1 deleted neurons reactivate several critical stem cell factors, suggesting that the cells potentially experience a reversion in cell identity. Considering these combined findings, the complexity of neuroepigenetics emerges: some epigenetic modifications must be actively preserved to maintain identity across the long life of the neuron. However, other modifications must be capable of dynamic change to allow for the rapid response of the neuron to its environment. Based on the ongoing function of these neuroepigenetic mechanisms in postmitotic neurons, it is tempting to speculate that oxidative toxicity, protein aggregates, and/or environmental factors could hinder the ability of genetically "normal" epigenetic players to perform their tasks, compromising a host of downstream pathways necessary for neuronal cell health.

\section{Final thoughts}

Since neurons are post-mitotic, it was not necessarily clear that they would require epigenetic mechanisms that regulate gene transcription. However, we have highlighted a few emerging examples of how epigenetic mechanisms may be functioning in neurological disease. These examples clearly demonstrate the need for epigenetic regulation in the nervous system, but because there are relatively few examples thus far, no unifying mechanisms have yet emerged. Nevertheless, we have discussed cases where the function of epigenetic modifying enzymes may be different in post-mitotic neurons than in dividing cells. In addition, we have highlighted an example of how an epigenetic enzyme that normally functions during cell fate transitions may instead be functioning to maintain the terminally differentiated state of post-mitotic neurons. These examples illustrate the need to think about epigenetic mechanisms in post-mitotic cells differently. Perhaps by doing so, it will enable us to uncover further examples of how altered epigenetic mechanisms may be contributing to neurological disease.

\begin{abstract}
Abbreviations
DNMT: DNA (cytosine-5) methyltransferase; $5 \mathrm{mC}$ : 5-methylcytosine; $5 \mathrm{hmC}$ : 5-hydroxymethylcytosine; 5fC: 5 -formylcytosine; $5 \mathrm{caC}$ : 5-carboxylcytosine; TET: ten-eleven translocase; TDG: thymine-DNA glycosylase; INTACT: isolation of nuclei tagged in specific cell types; MLL: mixed lineage leukemia; SET: Su(var)3-9, enhancer of zeste and trithorax; LSD: lysine-specific histone demethylase; Imj: Jumonji domain; JARID: Jmj/ARID domain-containing demethylase; SUV: suppressor of variegation; EHMT: euchromatic histone-lysine $\mathrm{N}$-methyltransferase; EZH2: enhancer of zeste homology 2; PRC: polycomb repressor complex; UTX: ubiquitously transcribed tetratricopeptide repeat X chromosome; Xist: X-inactive specific transcript; YY1: Yin Yang 1; HOTAIR: Hox transcript antisense RNA; piRNA: Piwi-interacting RNA; MECP: methylCpG-binding protein; HDAC: histone deacetylase; RTT: Rett syndrome; FXS: Fragile X syndrome; FMR1: Fragile X mental retardation 1; FMRP: Fragile X mental retardation protein; UTR: untranslated region; ESC: embryonic stem cells; ChIRP: chromatin isolation by RNA purification; AD: Alzheimer's disease; $A \beta$ : beta-amyloid protein; BACE: $\beta$-secretase protein; APOE: apolipoprotein E; NFT: neurofibrillary tangles; REST: RE1-silencing transcription factor; CtBP: C-terminal binding protein; FTD: frontotemporal dementia; LBD: Lewy body dementia; NuRD: nucleosome remodeling deacetylase.
\end{abstract}

Authors' contributions

MAC, SMK, and DJK wrote the manuscript. All authors read and approved the final manuscript.

\section{Author details}

${ }^{1}$ Department of Cell Biology, Emory University School of Medicine, 615 Michael Street, Atlanta, GA 30322, USA. ${ }^{2}$ Department of Molecular, Cell and Developmental Biology, University of California, Los Angeles, Los Angeles, CA 90095-7239, USA.

\section{Acknowledgements}

We would like to thank T. Lee, A. Scott, A. Engstrom, B. Kelly, and H. Gabel for their thoughtful comments on the manuscript.

\section{Competing interests}

The authors declare that they have no competing interests.

Availability of data and materials

Not applicable.

Consent for publication

Not applicable.

Ethics approval and consent to participate

Not applicable.

\section{Funding}

SMK was supported by the Emory CND training grant (T32NS007480). MAC was supported by the Emory GMB training grant (T32GM008490). This work was supported by a grant to DJK from the National Institute of Neurological Disorders and Stroke (1R01NS087142).

\section{Publisher's Note}

Springer Nature remains neutral with regard to jurisdictional claims in published maps and institutional affiliations. 
Received: 9 June 2017 Accepted: 23 August 2017

Published online: 16 October 2017

\section{References}

1. Hanahan D, Weinberg RA. Hallmarks of cancer: the next generation. Cell. 2011;144(5):646-74. doi:10.1016/j.cell.2011.02.013.

2. Feinberg AP, Vogelstein B. Hypomethylation distinguishes genes of some human cancers from their normal counterparts. Nature. 1983;301:89-92.

3. Feinberg AP, Tycko B. The history of cancer epigenetics. Nat Rev Cancer. 2004:4(2):143-53. doi:10.1038/nrc1279.

4. Hwang JY, Aromolaran KA, Zukin RS. The emerging field of epigenetics in neurodegeneration and neuroprotection. Nat Rev Neurosci. 2017;18(6):347-61. doi:10.1038/nrn.2017.46.

5. Sweatt JD. The emerging field of neuroepigenetics. Neuron. 2013;80(3):624-32. doi:10.1016/j.neuron.2013.10.023.

6. Yao B, Christian KM, He C, Jin P, Ming GL, Song H. Epigenetic mechanisms in neurogenesis. Nat Rev Neurosci. 2016;17(9):537-49. doi:10.1038/nrn.2016.70

7. Cooper DN, Taggart MH, Bird AP. Unmethylated domains in vertebrate DNA. Nucleic Acids Res. 1983;11(3):647-58

8. Bird AP. CpG-rich islands and the function of DNA methylation. Nature. 1986;321(6067):209-13. doi:10.1038/321209a0.

9. Coulondre C, Miller JH, Farabaugh PJ, Gilbert W. Molecular basis of base substitution hotspots in Escherichia coli. Nature. 1978;274(5673):775-80.

10. Watt F, Molloy PL. Cytosine methylation prevents binding to DNA of a HeLa cell transcription factor required for optimal expression of the adenovirus major late promoter. Genes Dev. 1988;2(9):1136-43.

11. Ben-Hattar J, Jiricny J. Methylation of single CpG dinucleotides within a promoter element of the Herpes simplex virus tk gene reduces its transcription in vivo. Gene. 1988:65(2):219-27.

12. Iguchi-Ariga SM, Schaffner W. CpG methylation of the CAMPresponsive enhancer/promoter sequence TGACGTCA abolishes specific factor binding as well as transcriptional activation. Genes Dev. 1989:3(5):612-9.

13. Ball MP, Li JB, Gao Y, Lee JH, LeProust EM, Park IH, et al. Targeted and genome-scale strategies reveal gene-body methylation signatures in human cells. Nat Biotechnol. 2009;27(4):361-8. doi:10.1038/nbt.1533.

14. Lister R, Pelizzola M, Dowen RH, Hawkins RD, Hon G, Tonti-Filippini J, et al. Human DNA methylomes at base resolution show widespread epigenomic differences. Nature. 2009;462(7271):315-22. doi:10.1038/ nature08514.

15. Guo JU, Ma DK, Mo H, Ball MP, Jang MH, Bonaguidi MA, et al. Neuronal activity modifies the DNA methylation landscape in the adult brain. Nat Neurosci. 2011;14(10):1345-51. doi:10.1038/nn.2900.

16. Lister R, Mukamel EA, Nery JR, Urich M, Puddifoot CA, Johnson ND, et al. Global epigenomic reconfiguration during mammalian brain development. Science. 2013;341(6146):1237905. doi:10.1126/science.1237905.

17. Okano M, Bell DW, Haber DA, Li E. DNA methyltransferases Dnmt3a and Dnmt3b are essential for de novo methylation and mammalian development. Cell. 1999:99(3):247-57.

18. Leonhardt H, Page AW, Weier HU, Bestor TH. A targeting sequence directs DNA methyltransferase to sites of DNA replication in mammalian nuclei. Cell. 1992;71(5):865-73.

19. Kaas GA, Zhong C, Eason DE, Ross DL, Vachhani RV, Ming GL, et al. TET1 controls CNS 5-methylcytosine hydroxylation, active DNA demethylation, gene transcription, and memory formation. Neuron. 2013;79(6):1086-93. doi:10.1016/j.neuron.2013.08.032.

20. Roth ED, Roth TL, Money KM, SenGupta S, Eason DE, Sweatt JD. DNA methylation regulates neurophysiological spatial representation in memory formation. Neuroepigenetics. 2015;2:1-8. doi:10.1016/j. nepig.2015.03.001.

21. Martinowich $K$, Hattori D, Wu H, Fouse S, He F, Hu Y, et al. DNA methylation-related chromatin remodeling in activity-dependent BDNF gene regulation. Science. 2003;302(5646):890-3. doi:10.1126/ science.1090842.

22. Ma DK, Jang MH, Guo JU, Kitabatake Y, Chang ML, Pow-Anpongkul N, et al. Neuronal activity-induced Gadd45b promotes epigenetic DNA demethylation and adult neurogenesis. Science. 2009;323(5917):10747. doi:10.1126/science.1166859.

23. Levenson JM, Roth TL, Lubin FD, Miller CA, Huang IC, Desai P, et al. Evidence that DNA (cytosine-5) methyltransferase regulates synaptic plasticity in the hippocampus. J Biol Chem. 2006;281(23):15763-73. doi:10.1074/jbc.M511767200.

24. Miller CA, Gavin CF, White JA, Parrish RR, Honasoge A, Yancey CR, et al. Cortical DNA methylation maintains remote memory. Nat Neurosci. 2010;13(6):664-6. doi:10.1038/nn.2560.

25. Feng J, Zhou Y, Campbell SL, Le T, Li E, Sweatt JD, et al. Dnmt1 and Dnmt3a maintain DNA methylation and regulate synaptic function in adult forebrain neurons. Nat Neurosci. 2010;13(4):423-30. doi:10.1038/ nn.2514.

26. Tahiliani M, Koh KP, Shen Y, Pastor WA, Bandukwala H, Brudno Y, et al. Conversion of 5-methylcytosine to 5-hydroxymethylcytosine in mammalian DNA by MLL partner TET1. Science. 2009;324(5929):930-5. doi:10.1126/science.1170116.

27. Ito S, Shen L, Dai Q, Wu SC, Collins LB, Swenberg JA, et al. Tet proteins can convert 5-methylcytosine to 5-formylcytosine and 5-carboxylcytosine. Science. 2011:333(6047):1300-3. doi:10.1126/science.1210597.

28. Guo JU, Su Y, Zhong C, Ming GL, Song H. Hydroxylation of 5-methylcytosine by TET1 promotes active DNA demethylation in the adult brain. Cell. 2011;145(3):423-34. doi:10.1016/j.cell.2011.03.022.

29. Kriaucionis S, Heintz N. The nuclear DNA base 5-hydroxymethylcytosine is present in Purkinje neurons and the brain. Science. 2009;324(5929):929-30. doi:10.1126/science.1169786.

30. Munzel M, Globisch D, Bruckl T, Wagner M, Welzmiller V, Michalakis S, et al. Quantification of the sixth DNA base hydroxymethylcytosine in the brain. Angew Chem Int Ed Engl. 2010;49(31):5375-7. doi:10.1002/ anie.201002033.

31. Szulwach KE, Li X, Li Y, Song CX, Wu H, Dai Q, et al. 5-hmC-mediated epigenetic dynamics during postnatal neurodevelopment and aging Nat Neurosci. 2011;14(12):1607-16. doi:10.1038/nn.2959.

32. Mellen M, Ayata P, Dewell S, Kriaucionis S, Heintz N. MeCP2 binds to $5 \mathrm{hmC}$ enriched within active genes and accessible chromatin in the nervous system. Cell. 2012;151(7):1417-30. doi:10.1016/j. cell.2012.11.022.

33. Rudenko A, Dawlaty MM, Seo J, Cheng AW, Meng J, Le T, et al. Tet1 is critical for neuronal activity-regulated gene expression and memory extinction. Neuron. 2013;79(6):1109-22. doi:10.1016/j. neuron.2013.08.003

34. Yu H, Su Y, Shin J, Zhong C, Guo JU, Weng YL, et al. Tet3 regulates synaptic transmission and homeostatic plasticity via DNA oxidation and repair. Nat Neurosci. 2015;18(6):836-43. doi:10.1038/nn.4008.

35. Shen L, Wu H, Diep D, Yamaguchi S, D'Alessio AC, Fung HL, et al. Genome-wide analysis reveals TET- and TDG-dependent 5-methylcytosine oxidation dynamics. Cell. 2013;153(3):692-706. doi:10.1016/j. cell.2013.04.002.

36. He YF, Li BZ, Li Z, Liu P, Wang Y, Tang Q, et al. Tet-mediated formation of 5-carboxylcytosine and its excision by TDG in mammalian DNA. Science. 2011:333(6047):1303-7. doi:10.1126/science.1210944.

37. Kellinger MW, Song CX, Chong J, Lu XY, He C, Wang D. 5-formylcytosine and 5-carboxylcytosine reduce the rate and substrate specificity of RNA polymerase II transcription. Nat Struct Mol Biol. 2012;19(8):831-3. doi:10.1038/nsmb.2346.

38. Xie W, Barr CL, Kim A, Yue F, Lee AY, Eubanks J, et al. Base-resolution analyses of sequence and parent-of-origin dependent DNA methylation in the mouse genome. Cell. 2012;148(4):816-31. doi:10.1016/j. cell.2011.12.035.

39. Guo JU, Su Y, Shin JH, Shin J, Li H, Xie B, et al. Distribution, recognition and regulation of non- $\mathrm{CpG}$ methylation in the adult mammalian brain. Nat Neurosci. 2014;17(2):215-22. doi:10.1038/nn.3607.

40. Lister R, Ecker JR. Finding the fifth base: genome-wide sequencing of cytosine methylation. Genome Res. 2009;19(6):959-66. doi:10.1101/ gr.083451.108.

41. Mo A, Mukamel EA, Davis FP, Luo C, Henry GL, Picard S, et al. Epigenomic signatures of neuronal diversity in the mammalian brain. Neuron. 2015:86(6):1369-84. doi:10.1016/j.neuron.2015.05.018.

42. Deal RB, Henikoff S. A simple method for gene expression and chromatin profiling of individual cell types within a tissue. Dev Cell. 2010;18(6):1030-40. doi:10.1016/j.devcel.2010.05.013. 
43. Worcel A, Han S, Wong ML. Assembly of newly replicated chromatin. Cell. 1978;15(3):969-77.

44. Smith S, Stillman B. Stepwise assembly of chromatin during DNA replication in vitro. EMBO J. 1991;10(4):971-80.

45. Whitlock JP Jr, Simpson RT. Localization of the sites along nucleosome DNA which interact with NH2-terminal histone regions. J Biol Chem. 1977;252(18):6516-20.

46. Ausio J, Dong F, van Holde KE. Use of selectively trypsinized nucleosome core particles to analyze the role of the histone "tails" in the stabilization of the nucleosome. J Mol Biol. 1989;206(3):451-63.

47. Brownell JE, Allis CD. An activity gel assay detects a single, catalytically active histone acetyltransferase subunit in Tetrahymena macronuclei. Proc Natl Acad Sci USA. 1995;92(14):6364-8.

48. Brownell JE, Zhou J, Ranalli T, Kobayashi R, Edmondson DG, Roth SY, et al. Tetrahymena histone acetyltransferase A: a homolog to yeast Gcn5p linking histone acetylation to gene activation. Cell. 1996;84(6):843-51.

49. Rea S, Eisenhaber F, O'Carroll D, Strahl BD, Sun ZW, Schmid M, et al. Regulation of chromatin structure by site-specific histone $\mathrm{H} 3$ methyltransferases. Nature. 2000;406(6796):593-9. doi:10.1038/35020506.

50. Taunton J, Hassig CA, Schreiber SL. A mammalian histone deacetylase related to the yeast transcriptional regulator Rpd3p. Science. 1996;272(5260):408-11.

51. Shi Y, Lan F, Matson C, Mulligan P, Whetstine JR, Cole PA, et al. Histone demethylation mediated by the nuclear amine oxidase homolog LSD1. Cell. 2004;119(7):941-53. doi:10.1016/j.cell.2004.12.012.

52. Cote J, Quinn J, Workman JL, Peterson CL. Stimulation of GAL4 derivative binding to nucleosomal DNA by the yeast SWI/SNF complex. Science. 1994:265(5168):53-60.

53. Imbalzano AN, Kwon H, Green MR, Kingston RE. Facilitated binding of TATA-binding protein to nucleosomal DNA. Nature. 1994;370(6489):481-5. doi:10.1038/370481a0.

54. Kwon H, Imbalzano AN, Khavari PA, Kingston RE, Green MR Nucleosome disruption and enhancement of activator binding by a human SW1/SNF complex. Nature. 1994;370(6489):477-81. doi:10.1038/370477a0.

55. Jenuwein T, Allis CD. Translating the histone code. Science. 2001;293(5532):1074-80.

56. Kouzarides T. Chromatin modifications and their function. Cell. 2007:128(4):693-705. doi:10.1016/j.cell.2007.02.005.

57. Bannister AJ, Kouzarides T. Regulation of chromatin by histone modifications. Cell Res. 2011;21(3):381-95. doi:10.1038/cr.2011.22.

58. Mahadevan LC, Willis AC, Barratt MJ. Rapid histone H3 phosphorylation in response to growth factors, phorbol esters, okadaic acid, and protein synthesis inhibitors. Cell. 1991;65(5):775-83.

59. Lee JH, Skalnik DG. CpG-binding protein (CXXC finger protein 1) is a component of the mammalian Set1 histone H3-Lys4 methyltransferase complex, the analogue of the yeast Set1/COMPASS complex. J Biol Chem. 2005;280(50):41725-31. doi:10.1074/jbc.M508312200.

60. Dou Y, Milne TA, Tackett AJ, Smith ER, Fukuda A, Wysocka J, et al. Physical association and coordinate function of the $\mathrm{H} 3 \mathrm{~K} 4$ methyltransferase MLL1 and the H4 K16 acetyltransferase MOF. Cell. 2005;121(6):873-85. doi:10.1016/j.cell.2005.04.031.

61. Hughes CM, Rozenblatt-Rosen O, Milne TA, Copeland TD, Levine SS, Lee $\mathrm{JC}$, et al. Menin associates with a trithorax family histone methyltransferase complex and with the hoxc8 locus. Mol Cell. 2004;13(4):587-97.

62. Nakamura T, Mori T, Tada S, Krajewski W, Rozovskaia T, Wassell R, et al. ALL-1 is a histone methyltransferase that assembles a supercomplex of proteins involved in transcriptional regulation. Mol Cell. 2002;10(5):1119-28.

63. Greer EL, Shi Y. Histone methylation: a dynamic mark in health, disease and inheritance. Nat Rev Genet. 2012;13(5):343-57. doi:10.1038/ nrg3173.

64. Seward DJ, Cubberley G, Kim S, Schonewald M, Zhang L, Tripet B, et al. Demethylation of trimethylated histone $\mathrm{H} 3 \mathrm{Lys} 4$ in vivo by JARID1 JmjC proteins. Nat Struct Mol Biol. 2007;14(3):240-2. doi:10.1038/nsmb1200.

65. Xiang Y, Zhu Z, Han G, Ye X, Xu B, Peng Z, et al. JARID1B is a histone H3 lysine 4 demethylase up-regulated in prostate cancer. Proc Natl Acad Sci USA. 2007;104(49):19226-31. doi:10.1073/pnas.0700735104.

66. Tachibana M, Sugimoto K, Nozaki M, Ueda J, Ohta T, Ohki M, et al. G9a histone methyltransferase plays a dominant role in euchromatic histone $\mathrm{H} 3$ lysine 9 methylation and is essential for early embryogenesis. Genes Dev. 2002;16(14):1779-91. doi:10.1101/gad.989402.

67. Schultz DC, Ayyanathan K, Negorev D, Maul GG, Rauscher FJ 3rd. SETDB1: a novel KAP-1-associated histone H3, lysine 9-specific methyltransferase that contributes to HP1-mediated silencing of euchromatic genes by KRAB zinc-finger proteins. Genes Dev. 2002;16(8):919-32. doi:10.1101/gad.973302.

68. Nady N, Lemak A, Walker JR, Avvakumov GV, Kareta MS, Achour M, et al. Recognition of multivalent histone states associated with heterochromatin by UHRF1 protein. J Biol Chem. 2011;286(27):24300-11. doi:10.1074/jbc.M111.234104.

69. Rothbart SB, Dickson BM, Ong MS, Krajewski K, Houliston S, Kireev DB, et al. Multivalent histone engagement by the linked tandem Tudor and PHD domains of UHRF1 is required for the epigenetic inheritance of DNA methylation. Genes Dev. 2013;27(11):1288-98. doi:10.1101/ gad.220467.113.

70. Yamane K, Toumazou C, Tsukada Y, Erdjument-Bromage $H$, Tempst $P$, Wong J, et al. JHDM2A, a JmjC-containing H3K9 demethylase, facilitates transcription activation by androgen receptor. Cell. 2006;125(3):483-95. doi:10.1016/j.cell.2006.03.027.

71. Laible PD, Greenfield SR, Wasielewski MR, Hansen DK, Pearlstein RM. Antenna excited state decay kinetics establish primary electron transfer in reaction centers as heterogeneous. Biochemistry. 1997;36(29):867785. doi:10.1021/bi970672a.

72. Lee MG, Villa R, Trojer P, Norman J, Yan KP, Reinberg D, et al. Demethylation of $\mathrm{H} 3 \mathrm{~K} 27$ regulates polycomb recruitment and $\mathrm{H} 2 \mathrm{~A}$ ubiquitination. Science. 2007;318(5849):447-50. doi:10.1126/science.1149042.

73. Xiang Y, Zhu Z, Han G, Lin H, Xu L, Chen CD. JMJD3 is a histone H3K27 demethylase. Cell Res. 2007;17(10):850-7. doi:10.1038/cr.2007.83.

74. Rose NR, Klose RJ. Understanding the relationship between DNA methylation and histone lysine methylation. Biochem Biophys Acta. 2014;1839(12):1362-72. doi:10.1016/j.bbagrm.2014.02.007.

75. Guan JS, Haggarty SJ, Giacometti E, Dannenberg JH, Joseph N, Gao $J$, et al. HDAC2 negatively regulates memory formation and synaptic plasticity. Nature. 2009;459(7243):55-60. doi:10.1038/nature07925.

76. Morris MJ, Mahgoub M, Na ES, Pranav H, Monteggia LM. Loss of histone deacetylase 2 improves working memory and accelerates extinction learning. J Neurosci. 2013;33(15):6401-11. doi:10.1523/ JNEUROSCI.1001-12.2013.

77. Kim MS, Akhtar MW, Adachi M, Mahgoub M, Bassel-Duby R, Kavalali ET, et al. An essential role for histone deacetylase 4 in synaptic plasticity and memory formation. J Neurosci. 2012;32(32):10879-86. doi:10.1523/ JNEUROSCI.2089-12.2012.

78. Williams SR, Aldred MA, Der Kaloustian VM, Halal F, Gowans G, McLeod $\mathrm{DR}$, et al. Haploinsufficiency of HDAC4 causes brachydactyly mental retardation syndrome, with brachydactyly type $\mathrm{E}$, developmental delays, and behavioral problems. Am J Hum Genet. 2010;87(2):219-28. doi:10.1016/j.ajhg.2010.07.011.

79. Brockdorff N, Ashworth A, Kay GF, McCabe VM, Norris DP, Cooper PJ, et al. The product of the mouse Xist gene is a $15 \mathrm{~kb}$ inactive $X$-specific transcript containing no conserved ORF and located in the nucleus. Cell. 1992;71(3):515-26.

80. Brown CJ, Hendrich BD, Rupert JL, Lafreniere RG, Xing Y, Lawrence J, et al. The human XIST gene: analysis of a $17 \mathrm{~kb}$ inactive X-specific RNA that contains conserved repeats and is highly localized within the nucleus. Cell. 1992;71(3):527-42.

81. Clemson CM, McNeil JA, Willard HF, Lawrence JB. XIST RNA paints the inactive $X$ chromosome at interphase: evidence for a novel RNA involved in nuclear/chromosome structure. J Cell Biol. 1996;132(3):259-75

82. Zhao J, Sun BK, Erwin JA, Song JJ, Lee JT. Polycomb proteins targeted by a short repeat RNA to the mouse X chromosome. Science. 2008;322(5902):750-6. doi:10.1126/science.1163045.

83. Jeon $Y$, Lee JT. YY1 tethers Xist RNA to the inactive $X$ nucleation center. Cell. 2011;146(1):119-33. doi:10.1016/j.cell.2011.06.026.

84. Tsai MC, Manor O, Wan Y, Mosammaparast N, Wang JK, Lan F, et al. Long noncoding RNA as modular scaffold of histone modification complexes. Science. 2010;329(5992):689-93. doi:10.1126/science.1192002.

85. Weick EM, Miska EA. piRNAs: from biogenesis to function. Development. 2014;141(18):3458-71. doi:10.1242/dev.094037. 
86. Lewis JD, Meehan RR, Henzel WJ, Maurer-Fogy I, Jeppesen P, Klein F, et al. Purification, sequence, and cellular localization of a novel chromosomal protein that binds to methylated DNA. Cell. 1992;69(6):905-14.

87. Hassig CA, Fleischer TC, Billin AN, Schreiber SL, Ayer DE. Histone deacetylase activity is required for full transcriptional repression by $\mathrm{mSin} 3 \mathrm{~A}$. Cell. 1997:89(3):341-7.

88. Laherty CD, Yang WM, Sun JM, Davie JR, Seto E, Eisenman RN. Histone deacetylases associated with the mSin3 corepressor mediate mad transcriptional repression. Cell. 1997;89(3):349-56.

89. Nagy L, Kao HY, Chakravarti D, Lin RJ, Hassig CA, Ayer DE, et al. Nuclear receptor repression mediated by a complex containing SMRT, mSin3A, and histone deacetylase. Cell. 1997;89(3):373-80.

90. Nan $\mathrm{X}, \mathrm{Ng} \mathrm{HH}$, Johnson CA, Laherty CD, Turner BM, Eisenman RN, et al. Transcriptional repression by the methyl-CpG-binding protein MeCP2 involves a histone deacetylase complex. Nature. 1998;393(6683):386-9. doi:10.1038/30764.

91. Skene PJ, Illingworth RS, Webb S, Kerr AR, James KD, Turner DJ, et al. Neuronal MeCP2 is expressed at near histone-octamer levels and globally alters the chromatin state. Mol Cell. 2010;37(4):457-68. doi:10.1016/j.molcel.2010.01.030.

92. Samaco RC, Nagarajan RP, Braunschweig D, LaSalle JM. Multiple pathways regulate MeCP2 expression in normal brain development and exhibit defects in autism-spectrum disorders. Hum Mol Genet. 2004;13(6):629-39. doi:10.1093/hmg/ddh063.

93. Jung BP, Jugloff DG, Zhang G, Logan R, Brown S, Eubanks JH. The expression of methyl CpG binding factor MeCP2 correlates with cellular differentiation in the developing rat brain and in cultured cells. J Neurobiol. 2003;55(1):86-96. doi:10.1002/neu.10201.

94. Kishi N, Macklis JD. Dissecting MECP2 function in the central nervous system. J Child Neurol. 2005;20(9):753-9. doi:10.1177/08830738050200 091001.

95. Amir RE, Van den Veyver IB, Wan M, Tran CQ, Francke U, Zoghbi HY. Rett syndrome is caused by mutations in X-linked MECP2, encoding methyl-CpG-binding protein 2. Nat Genet. 1999;23(2):185-8. doi:10.1038/13810.

96. Schule B, Armstrong DD, Vogel H, Oviedo A, Francke U. Severe congenital encephalopathy caused by MECP2 null mutations in males: central hypoxia and reduced neuronal dendritic structure. Clin Genet. 2008;74(2):116-26. doi:10.1111/j.1399-0004.2008.01005.x.

97. Lyst MJ, Bird A. Rett syndrome: a complex disorder with simple roots. Nat Rev Genet. 2015;16(5):261-75. doi:10.1038/nrg3897.

98. Chen L, Chen K, Lavery LA, Baker SA, Shaw CA, Li W, et al. MeCP2 binds to non-CG methylated DNA as neurons mature, influencing transcription and the timing of onset for Rett syndrome. Proc Natl Acad Sci USA. 2015;112(17):5509-14. doi:10.1073/pnas.1505909112.

99. Kinde B, Gabel HW, Gilbert CS, Griffith EC, Greenberg ME. Reading the unique DNA methylation landscape of the brain: non-CpG methylation, hydroxymethylation, and MeCP2. Proc Natl Acad Sci USA. 2015;112(22):6800-6. doi:10.1073/pnas.1411269112.

100. Gabel HW, Kinde B, Stroud H, Gilbert CS, Harmin DA, Kastan NR, et al. Disruption of DNA-methylation-dependent long gene repression in Rett syndrome. Nature. 2015;522(7554):89-93. doi:10.1038/ nature14319.

101. Tatton-Brown K, Seal S, Ruark E, Harmer J, Ramsay E, Del Vecchio Duarte $S$, et al. Mutations in the DNA methyltransferase gene DNMT3A cause an overgrowth syndrome with intellectual disability. Nat Genet. 2014;46(4):385-8. doi:10.1038/ng.2917.

102. Sanders SJ, He X, Willsey AJ, Ercan-Sencicek AG, Samocha KE, Cicek AE, et al. Insights into autism spectrum disorder genomic architecture and biology from 71 risk loci. Neuron. 2015;87(6):1215-33. doi:10.1016/j. neuron.2015.09.016.

103. Fisch GS, Simensen RJ, Schroer RJ. Longitudinal changes in cognitive and adaptive behavior scores in children and adolescents with the fragile X mutation or autism. J Autism Dev Disord. 2002;32(2):107-14.

104. Ashley CT, Sutcliffe JS, Kunst CB, Leiner HA, Eichler EE, Nelson DL, et al. Human and murine FMR-1: alternative splicing and translational initiation downstream of the CGG-repeat. Nat Genet. 1993:4(3):244-51. doi:10.1038/ng0793-244.

105. Ashley CT Jr, Wilkinson KD, Reines D, Warren ST. FMR1 protein: conserved RNP family domains and selective RNA binding. Science. 1993;262(5133):563-6.
106. Hanson JE, Madison DV. Presynaptic FMR1 genotype influences the degree of synaptic connectivity in a mosaic mouse model of fragile X syndrome. J Neurosci. 2007;27(15):4014-8. doi:10.1523/ JNEUROSCI.4717-06.2007.

107. Pieretti M, Zhang FP, Fu YH, Warren ST, Oostra BA, Caskey CT, et al. Absence of expression of the FMR-1 gene in fragile $X$ syndrome. Cell. 1991;66(4):817-22.

108. Verheij C, Bakker CE, de GraaffE, Keulemans J, Willemsen R, Verkerk AJ, et al. Characterization and localization of the FMR-1 gene product associated with fragile X syndrome. Nature. 1993;363(6431):722-4. doi:10.1038/363722a0.

109. Coffee B, Zhang F, Warren ST, Reines D. Acetylated histones are associated with FMR1 in normal but not fragile X-syndrome cells. Nat Genet. 1999;22(1):98-101. doi:10.1038/8807.

110. Coffee B, Zhang F, Ceman S, Warren ST, Reines D. Histone modifications depict an aberrantly heterochromatinized FMR1 gene in fragile $x$ syndrome. Am J Hum Genet. 2002;71(4):923-32. doi:10.1086/342931.

111. Fu YH, Kuhl DP, Pizzuti A, Pieretti M, Sutcliffe JS, Richards S, et al. Variation of the CGG repeat at the fragile $X$ site results in genetic instability: resolution of the Sherman paradox. Cell. 1991;67(6):1047-58.

112. Hagerman RJ, Leehey M, Heinrichs W, Tassone F, Wilson R, Hills J, et al. Intention tremor, parkinsonism, and generalized brain atrophy in male carriers of fragile X. Neurology. 2001;57(1):127-30.

113. Tassone F, Beilina A, Carosi C, Albertosi S, Bagni C, Li L, et al. Elevated FMR1 mRNA in premutation carriers is due to increased transcription. RNA. 2007;13(4):555-62. doi:10.1261/rna.280807.

114. Eiges R, Urbach A, Malcov M, Frumkin T, Schwartz T, Amit A, et al. Developmental study of fragile $X$ syndrome using human embryonic stem cells derived from preimplantation genetically diagnosed embryos. Cell Stem Cell. 2007;1(5):568-77. doi:10.1016/j.stem.2007.09.001.

115. Colak D, Zaninovic N, Cohen MS, Rosenwaks Z, Yang WY, Gerhardt J, et al. Promoter-bound trinucleotide repeat mRNA drives epigenetic silencing in fragile $X$ syndrome. Science. 2014;343(6174):1002-5. doi:10.1126/science.1245831.

116. Rademakers R, Rovelet-Lecrux A. Recent insights into the molecular genetics of dementia. Trends Neurosci. 2009;32(8):451-61. doi:10.1016/j. tins.2009.05.005.

117. Palop JJ, Chin J, Mucke L. A network dysfunction perspective on neurodegenerative diseases. Nature. 2006;443(7113):768-73. doi:10.1038/ nature05289.

118. Putcha D, Brickhouse M, O'Keefe K, Sullivan C, Rentz D, Marshall G, et al. Hippocampal hyperactivation associated with cortical thinning in Alzheimer's disease signature regions in non-demented elderly adults. J Neurosci. 2011:31(48):17680-8. doi:10.1523/JNEUROSCI.4740-11.2011.

119. Sperling RA, Dickerson BC, Pihlajamaki M, Vannini P, LaViolette PS, Vitolo OV, et al. Functional alterations in memory networks in early Alzheimer's disease. Neuromol Med. 2010;12(1):27-43. doi:10.1007/ s12017-009-8109-7.

120. Glenner GG, Wong CW. Alzheimer's disease and Down's syndrome: sharing of a unique cerebrovascular amyloid fibril protein. Biochem Biophys Res Commun. 1984;122(3):1131-5.

121. Masters CL, Multhaup G, Simms G, Pottgiesser J, Martins RN, Beyreuther K. Neuronal origin of a cerebral amyloid: neurofibrillary tangles of Alzheimer's disease contain the same protein as the amyloid of plaque cores and blood vessels. EMBO J. 1985;4(11):2757-63 Epub 1985/11/01

122. Kang J, Lemaire HG, Unterbeck A, Salbaum JM, Masters CL, Grzeschik $\mathrm{KH}$, et al. The precursor of Alzheimer's disease amyloid A4 protein resembles a cell-surface receptor. Nature. 1987;325(6106):733-6. doi:10.1038/325733a0.

123. Vassar R, Bennett BD, Babu-Khan S, Kahn S, Mendiaz EA, Denis P, et al. Beta-secretase cleavage of Alzheimer's amyloid precursor protein by the transmembrane aspartic protease BACE. Science. 1999:286(5440):735-41.

124. Esch FS, Keim PS, Beattie EC, Blacher RW, Culwell AR, OltersdorfT, et al. Cleavage of amyloid beta peptide during constitutive processing of its precursor. Science. 1990;248(4959):1122-4

125. Wolfe MS, Xia W, Ostaszewski BL, DiehI TS, Kimberly WT, Selkoe DJ. Two transmembrane aspartates in presenilin-1 required for presenilin endoproteolysis and gamma-secretase activity. Nature. 1999;398(6727):5137. doi:10.1038/19077. 
126. Vetrivel KS, Zhang YW, Xu H, Thinakaran G. Pathological and physiological functions of presenilins. Mol Neurodegener. 2006;1:4. doi:10.1186/1750-1326-1-4.

127. Rogaev El, Sherrington R, Rogaeva EA, Levesque G, Ikeda M, Liang Y, et al. Familial Alzheimer's disease in kindreds with missense mutations in a gene on chromosome 1 related to the Alzheimer's disease type 3 gene. Nature. 1995;376(6543):775-8. doi:10.1038/376775a0.

128. Sherrington R, Rogaev El, Liang Y, Rogaeva EA, Levesque G, Ikeda $\mathrm{M}$, et al. Cloning of a gene bearing missense mutations in earlyonset familial Alzheimer's disease. Nature. 1995;375(6534):754-60. doi:10.1038/375754a0.

129. Price $J$, Morris JC. Tangles and plaques in nondemented aging and "preclinical" Alzheimer's disease. Ann Neurol. 1999;45(3):358-68 Epub 1999/03/11

130. Arriagada PV, Growdon JH, Hedley-Whyte ET, Hyman BT. Neurofibrillary tangles but not senile plaques parallel duration and severity of Alzheimer's disease. Neurology. 1992;42(3 Pt 1):631-9.

131. Bramblett GT, Goedert M, Jakes R, Merrick SE, Trojanowski JQ, Lee VM. Abnormal tau phosphorylation at Ser396 in Alzheimer's disease recapitulates development and contributes to reduced microtubule binding. Neuron. 1993;10(6):1089-99.

132. Cohen TJ, Guo JL, Hurtado DE, Kwong LK, Mills IP, Trojanowski JQ et al. The acetylation of tau inhibits its function and promotes pathological tau aggregation. Nat Commun. 2011;2:252. doi:10.1038/ncomms1255.

133. Drechsel DN, Hyman AA, Cobb MH, Kirschner MW. Modulation of the dynamic instability of tubulin assembly by the microtubule-associated protein tau. Mol Biol Cell. 1992:3(10):1141-54

134. Bertram L, Lill CM, Tanzi RE. The genetics of Alzheimer disease: back to the future. Neuron. 2010;68(2):270-81. doi:10.1016/j. neuron.2010.10.013

135. Morris M, Maeda S, Vossel K, Mucke L. The many faces of tau. Neuron. 2011;70(3):410-26. doi:10.1016/j.neuron.2011.04.009.

136. Morris M, Hamto P, Adame A, Devidze N, Masliah E, Mucke L. Ageappropriate cognition and subtle dopamine-independent motor deficits in aged tau knockout mice. Neurobiol Aging. 2013;34(6):1523-9. doi:10.1016/j.neurobiolaging.2012.12.003.

137. Dickstein DL, Brautigam H, Stockton SD Jr, Schmeidler J, Hof PR. Changes in dendritic complexity and spine morphology in transgenic mice expressing human wild-type tau. Brain Struct Funct. 2010;214(23):161-79. doi:10.1007/s00429-010-0245-1.

138. Alldred MJ, Duff KE, Ginsberg SD. Microarray analysis of CA1 pyramidal neurons in a mouse model of tauopathy reveals progressive synaptic dysfunction. Neurobiol Dis. 2012;45(2):751-62. doi:10.1016/j. nbd.2011.10.022.

139. Polydoro M, Acker CM, Duff K, Castillo PE, Davies P. Age-dependent impairment of cognitive and synaptic function in the htau mouse model of tau pathology. J Neurosci. 2009;29(34):10741-9. doi:10.1523/ JNEUROSCI.1065-09.2009.

140. Tai HC, Wang BY, Serrano-Pozo A, Frosch MP, Spires-Jones TL, Hyman BT. Frequent and symmetric deposition of misfolded tau oligomers within presynaptic and postsynaptic terminals in Alzheimer's disease. Acta Neuropathol Commun. 2014;2:146. doi:10.1186/s40478-014-0146-2.

141. Wisniewski HM, Wegiel J. Spatial relationships between astrocytes and classical plaque components. Neurobiol Aging. 1991;12(5):593-600

\section{Epub 1991/09/01.}

142. Zhang B, Gaiteri C, Bodea LG, Wang Z, McElwee J, Podtelezhnikov AA, et al. Integrated systems approach identifies genetic nodes and networks in late-onset Alzheimer's disease. Cell. 2013;153(3):707-20. doi:10.1016/j.cell.2013.03.030.

143. Busser J, Geldmacher DS, Herrup K. Ectopic cell cycle proteins predict the sites of neuronal cell death in Alzheimer's disease brain. J Neurosci. 1998;18(8):2801-7 Epub 1998/04/29

144. D'Angelo MA, Raices M, Panowski SH, Hetzer MW. Age-dependent deterioration of nuclear pore complexes causes a loss of nuclear integrity in postmitotic cells. Cell. 2009;136(2):284-95. doi:10.1016/j. cell.2008.11.037.

145. Lin MT, Beal MF. Mitochondrial dysfunction and oxidative stress in neurodegenerative diseases. Nature. 2006;443(7113):787-95. doi:10.1038/ nature05292.

146. Corder EH, Saunders AM, Strittmatter WJ, Schmechel DE, Gaskell PC, Small GW, et al. Gene dose of apolipoprotein E type 4 allele and the risk of Alzheimer's disease in late onset families. Science. 1993;261(5123):921-3.

147. Lambert JC, Amouyel P. Genetic heterogeneity of Alzheimer's disease: complexity and advances. Psychoneuroendocrinology. 2007;32(Suppl 1):S62-70. doi:10.1016/j.psyneuen.2007.05.015.

148. Lu T, Aron L, Zullo J, Pan Y, Kim H, Chen Y, et al. REST and stress resistance in ageing and Alzheimer's disease. Nature. 2014;507(7493):448-54. doi:10.1038/nature13163.

149. Chong JA, Tapia-Ramirez J, Kim S, Toledo-Aral JJ, Zheng Y, Boutros MC, et al. REST: a mammalian silencer protein that restricts sodium channel gene expression to neurons. Cell. 1995;80(6):949-57.

150. Schoenherr CJ, Anderson DJ. The neuron-restrictive silencer factor (NRSF): a coordinate repressor of multiple neuron-specific genes. Science. 1995;267(5202):1360-3.

151. Roopra A, Qazi R, Schoenike B, Daley TJ, Morrison JF. Localized domains of G9a-mediated histone methylation are required for silencing of neuronal genes. Mol Cell. 2004;14(6):727-38. doi:10.1016/j. molcel.2004.05.026.

152. Ballas N, Grunseich C, Lu DD, Speh JC, Mandel G. REST and its corepressors mediate plasticity of neuronal gene chromatin throughout neurogenesis. Cell. 2005;121(4):645-57. doi:10.1016/j.cell.2005.03.013.

153. Ooi L, Wood IC. Chromatin crosstalk in development and disease: lessons from REST. Nat Rev Genet. 2007;8(7):544-54. doi:10.1038/nrg2100.

154. You A, Tong JK, Grozinger CM, Schreiber SL. CoREST is an integral component of the CoREST-human histone deacetylase complex. Proc Natl Acad Sci USA. 2001;98(4):1454-8.

155. Lee MG, Wynder C, Cooch N, Shiekhattar R. An essential role for COREST in nucleosomal histone 3 lysine 4 demethylation. Nature. 2005:437(7057):432-5. doi:10.1038/nature04021.

156. Metzger E, Wissmann M, Yin N, Muller JM, Schneider R, Peters AH, et al. LSD1 demethylates repressive histone marks to promote androgenreceptor-dependent transcription. Nature. 2005;437(7057):436-9.

157. Katz DJ, Edwards TM, Reinke V, Kelly WG. A C. elegans LSD1 demethylase contributes to germline immortality by reprogramming epigenetic memory. Cell. 2009;137(2):308-20. doi:10.1016/j.cell.2009.02.015.

158. Rudolph T, Yonezawa M, Lein S, Heidrich K, Kubicek S, Schafer C, et al. Heterochromatin formation in Drosophila is initiated through active removal of H3K4 methylation by the LSD1 homolog SU(VAR)3-3. Mol Cell. 2007;26(1):103-15. doi:10.1016/j.molcel.2007.02.025.

159. Di Stefano L, Ji JY, Moon NS, Herr A, Dyson N. Mutation of Drosophila Lsd1 disrupts H3-K4 methylation, resulting in tissue-specific defects during development. Curr Biol. 2007;17(9):808-12. doi:10.1016/j. cub.2007.03.068.

160. Szabad J, Reuter G, Schroder MB. The effects of two mutations connected with chromatin functions on female germ-line cells of Drosophila. Mol Gen Genet. 1988;211(1):56-62.

161. Ancelin K, Syx L, Borensztein M, Ranisavljevic N, Vassilev I, Briseno-Roa L, et al. Maternal LSD1/KDM1A is an essential regulator of chromatin and transcription landscapes during zygotic genome activation. Elife. 2016; doi:10.7554/eLife.08851.

162. Wasson JA, Simon AK, Myrick DA, Wolf G, Driscoll S, Pfaff SL, et al. Maternally provided LSD1/KDM1A enables the maternal-to-zygotic transition and prevents defects that manifest postnatally. Elife. 2016: doi:10.7554/ elife.08848.

163. Whyte WA, Bilodeau S, Orlando DA, Hoke HA, Frampton GM, Foster CT, et al. Enhancer decommissioning by LSD1 during embryonic stem cell differentiation. Nature. 2012:482(7384):221-5. doi:10.1038/nature10805.

164. Kerenyi MA, Shao Z, Hsu YJ, Guo G, Luc S, O'Brien K, et al. Histone demethylase Lsd1 represses hematopoietic stem and progenitor cell signatures during blood cell maturation. Elife. 2013;2:e00633. doi:10.7554/ elife.00633.

165. Wang J, Scully K, Zhu X, Cai L, Zhang J, Prefontaine GG, et al. Opposing LSD1 complexes function in developmental gene activation and repression programmes. Nature. 2007:446(7138):882-7. doi:10.1038/ nature05671.

166. Wang J, Hevi S, Kurash JK, Lei H, Gay F, Bajko J, et al. The lysine demethylase LSD1 (KDM1) is required for maintenance of global DNA methylation. Nat Genet. 2009:41(1):125-9.

167. Su ST, Ying HY, Chiu YK, Lin FR, Chen MY, Lin KI. Involvement of histone demethylase LSD1 in Blimp-1-mediated gene repression during plasma 
cell differentiation. Mol Cell Biol. 2009;29(6):1421-31. doi:10.1128/ MCB.01158-08.

168. Saleque S, Kim J, Rooke HM, Orkin SH. Epigenetic regulation of hematopoietic differentiation by Gf- 1 and Gfi- $1 \mathrm{~b}$ is mediated by the cofactors CoREST and LSD1. Mol Cell. 2007;27(4):562-72. doi:10.1016/j. molcel.2007.06.039.

169. Zhu D, Holz S, Metzger E, Pavlovic M, Jandausch A, Jilg C, et al. Lysinespecific demethylase 1 regulates differentiation onset and migration of trophoblast stem cells. Nat Commun. 2014;5:3174. doi:10.1038/ ncomms4174.

170. Lyons DB, Allen WE, Goh T, Tsai L, Barnea G, Lomvardas S. An epigenetic trap stabilizes singular olfactory receptor expression. Cell. 2013;154(2):325-36. doi:10.1016/j.cell.2013.06.039.

171. Nam HJ, Boo K, Kim D, Han DH, Choe HK, Kim CR, et al. Phosphorylation of LSD1 by PKCalpha is crucial for circadian rhythmicity and phase resetting. Mol Cell. 2014;53(5):791-805. doi:10.1016/j. molcel.2014.01.028.

172. Siklenka K, Erkek S, Godmann M, Lambrot R, McGraw S, Lafleur C, et al. Disruption of histone methylation in developing sperm impairs offspring health transgenerationally. Science. 2015;350(6261):aab2006. doi:10.1126/science.aab2006.

173. Lambrot R, Lafleur C, Kimmins S. The histone demethylase KDM1A is essential for the maintenance and differentiation of spermatogonial stem cells and progenitors. FASEB J. 2015;. doi:10.1096/f.14-267328.

174. Duteil D, Metzger E, Willmann D, Karagianni P, Friedrichs N, Greschik H, et al. LSD1 promotes oxidative metabolism of white adipose tissue. Nat Commun. 2014:5:4093. doi:10.1038/ncomms5093.

175. Myrick DA, Christopher MA, Scott AM, Simon AK, Donlin-Asp PG, Kelly WG, et al. KDM1A/LSD1 regulates the differentiation and maintenance of spermatogonia in mice. PLoS ONE. 2017;12(5):e0177473. doi:10.1371/ journal.pone.0177473.

176. Fuentes P, Canovas J, Berndt FA, Noctor SC, Kukuljan M. CoREST/LSD1 control the development of pyramidal cortical neurons. Cereb Cortex. 2012;22(6):1431-41. doi:10.1093/cercor/bhr218.

177. Laurent B, Ruitu L, Murn J, Hempel K, Ferrao R, Xiang Y, et al. A specific LSD1/KDM1A isoform regulates neuronal differentiation through H3K9 demethylation. Mol Cell. 2015;57(6):957-70. doi:10.1016/j. molcel.2015.01.010
178. Zibetti C, Adamo A, Binda C, Forneris F, Toffolo E, Verpelli C, et al. Alternative splicing of the histone demethylase LSD1/KDM1 contributes to the modulation of neurite morphogenesis in the mammalian nervous system. J Neurosci. 2010;30(7):2521-32. doi:10.1523/ JNEUROSCI.5500-09.2010.

179. Wang J, Telese F, Tan Y, Li W, Jin C, He X, et al. LSD1n is an H4K20 demethylase regulating memory formation via transcriptional elongation control. Nat Neurosci. 2015;18(9):1256-64. doi:10.1038/nn.4069.

180. Pilotto S, Speranzini V, Marabelli C, Rusconi F, Toffolo E, Grillo B, et al. LSD1/KDM1A mutations associated to a newly described form of intellectual disability impair demethylase activity and binding to transcription factors. Hum Mol Genet. 2016;25(12):2578-87. doi:10.1093/hmg/ ddw120.

181. Christopher MA, Myrick DA, Barwick BG, Engstrom AK, Porter-Stransky KA, Boss JM, et al. LSD1 protects against hippocampal and cortical neurodegeneration. Nat Commun. 2017;8(1):805. doi:10.1038/ s41467-017-00922-9.

182. Chen-Plotkin AS, Geser F, Plotkin JB, Clark CM, Kwong LK, Yuan W, et al. Variations in the progranulin gene affect global gene expression in frontotemporal lobar degeneration. Hum Mol Genet. 2008;17(10):134962. doi:10.1093/hmg/ddn023.

183. Al-Mahdawi S, Virmouni SA, Pook MA. The emerging role of 5-hydroxymethylcytosine in neurodegenerative diseases. Front Neurosci. 2014;8:397. doi:10.3389/fnins.2014.00397.

184. Tohgi H, Utsugisawa K, Nagane Y, Yoshimura M, Ukitsu M, Genda Y. The methylation status of cytosines in a tau gene promoter region alters with age to downregulate transcriptional activity in human cerebral cortex. Neurosci Lett. 1999;275(2):89-92.

185. Frost B, Hemberg M, Lewis J, Feany MB. Tau promotes neurodegeneration through global chromatin relaxation. Nat Neurosci. 2014;17(3):35766. doi:10.1038/nn.3639.

\section{Submit your next manuscript to BioMed Central and we will help you at every step:}

- We accept pre-submission inquiries

- Our selector tool helps you to find the most relevant journal

- We provide round the clock customer support

- Convenient online submission

- Thorough peer review

- Inclusion in PubMed and all major indexing services

- Maximum visibility for your research

Submit your manuscript at www.biomedcentral.com/submit
() Biomed Central 